\title{
The effects of increased freshwater inflow on metal enrichment in selected Eastern Cape estuaries, South Africa
}

\author{
$\mathrm{KK}$ Orr $^{1 *}$, JE Burgess ${ }^{2}$ and PW Froneman ${ }^{1}$ \\ ${ }^{1}$ Department of Zoology and Entomology, Rhodes University, Grahamstown 6140, South Africa \\ ${ }^{2}$ Department of Biochemistry, Microbiology \& Biotechnology, Rhodes University, Grahamstown 6140, South Africa
}

\begin{abstract}
The concentrations of select metals ( $\mathrm{Cd}, \mathrm{Co}, \mathrm{Cu}, \mathrm{Fe}, \mathrm{Pb}, \mathrm{Ni}$ and $\mathrm{Zn}$ ) within the water column and sediment of the permanently open Kariega Estuary and temporary open/closed Riet and East Kleinemonde Estuaries were investigated during a dry and a wet season. Enrichment factors (EFs), using Fe as a reference element, and baseline linear regression models for metals vs Fe were used to assess the extent of metal enrichment in the sediments. The results of the study indicate that $\mathrm{Cd}$, $\mathrm{Co} \mathrm{Ni}$ and $\mathrm{Pb}$ were enriched above baseline concentrations $(1.0<\mathrm{EF}<4.1)$ in the sediments of all three estuaries. $\mathrm{Co}, \mathrm{Pb}$ and $\mathrm{Ni}$ enrichment in the Kariega Estuary sediments was significantly higher during the dry season, and the mean concentrations of $\mathrm{Pb}$ and $\mathrm{Cd}$ in the water column were 19-fold and 66-fold higher in the dry season. The elevated concentration of metals during the dry season could be related to accumulation of diffuse pollution from human activities within the catchment area. Conversely, inflow of freshwater into the estuary had the net effect of reducing the concentration and enrichment of these metals within the Kariega Estuary due to scouring and outflow of estuarine water and sediment into the marine environment.

The temporal variations in metal concentrations and enrichment factors were less pronounced in the temporary open/ closed estuaries than the Kariega Estuary. The observed trend can probably be related to the low anthropogenic impact within the catchment areas of these systems, and the relatively smaller size of the catchments. Significant spatial variations existed in metal enrichment in the sediment of both the East Kleinemonde and Riet Estuaries, with the highest degrees of enrichment occurring in the sediments from the marine environment and lower reaches.
\end{abstract}

Keywords: metal enrichment, estuaries, sediment and water, South Africa

\section{Introduction}

Estuaries may be the repositories of contaminants generated by human activities (Kennish, 1997). Metals typically bind to fine grained sediments, such as mud and organic matter. As a consequence of the sheltered nature of estuaries, these materials tend to settle out in estuaries, and thereby increase the propensity for contamination and accumulation in these environments. Metals, however, are not indefinitely bound to sediments and may be re-mobilised and returned to solution via physical, chemical and biological processes (De Groot et al., 1976). Concentrations of metals in the sediment are typically several orders of magnitude higher than those in the water column (Bryan and Langston, 1992), and thus the levels of metals within the water column may meet water quality guidelines for water use and ecological health but the sediment may not (Binning and Baird, 2001). The concentrations of metals in the water column are also subject to greater temporal and spatial variability than in the sediment, which makes it difficult to obtain water samples that are representative of the contaminant status of the water-body. Sediments, on the other hand, are long-term integrators of metals and provide a more accurate reflection of the extent of metal contamination within a particular system (Binning and Baird, 2001).

Metals are natural constituents of the environment, but their concentrations may become elevated as a result of human activities. Metals that are enriched above background concen-

\footnotetext{
* To whom all correspondence should be addressed.

용 +27 46 603-8525; fax: +27 46 622-8959;

e-mail: kylaorr@gmail.com

Received 21 May 2007; accepted in revised form 7 November 2007.
}

trations in the sediment and water column of estuaries are thus commonly used as an indicator of pollution (Biney et al., 1991; Binning and Baird, 2001). Metals commonly enter the aquatic environment via multiple anthropogenic non-point sources such as; storm-water run-off from roads, parking lots and residential areas; leaching of metals from dumping sites, fertilisers and pesticides; and atmospheric deposition of metals from combusted fuels. Identifying the sources of non-point pollution is problematic, and thus it is difficult to prevent the input of pollutants from non-point sources. It is for these reasons that non-point sources of pollution have been identified as one of the greatest threats to the health of aquatic environments (Buntsama and Casey-Lefkowitz, 1999; US-EPA, 1993). Metals may also be discharged directly into water systems from point-sources such as factory or municipal wastewater outfalls.

Increased urbanisation, agricultural and coastal developments within the Eastern Cape contribute to the diffuse and direct input of pollution into estuaries, and are an ever increasing threat to the health of estuarine systems (Scharler and Baird, 2003). Nonetheless, very few studies have been conducted on metals in Eastern Cape estuaries. In the late 1970s and early 1980s a broad marine pollution monitoring program was carried out along the South African coastline (Hennig, 1985) and more recent studies have been performed on the larger, industrialised Eastern Cape estuaries (Binning and Baird, 2001; Fatoki and Mathabatha, 2001). To date, no metal studies have been conducted on the smaller, more pristine temporary open/closed systems such as the Riet and East Kleinemonde Estuaries, and a single survey was conducted on the Kariega in the late 1980s (Watling, 1988).

The aims of this study were thus to investigate the influence of seasonally associated differences in rainfall, and hence 


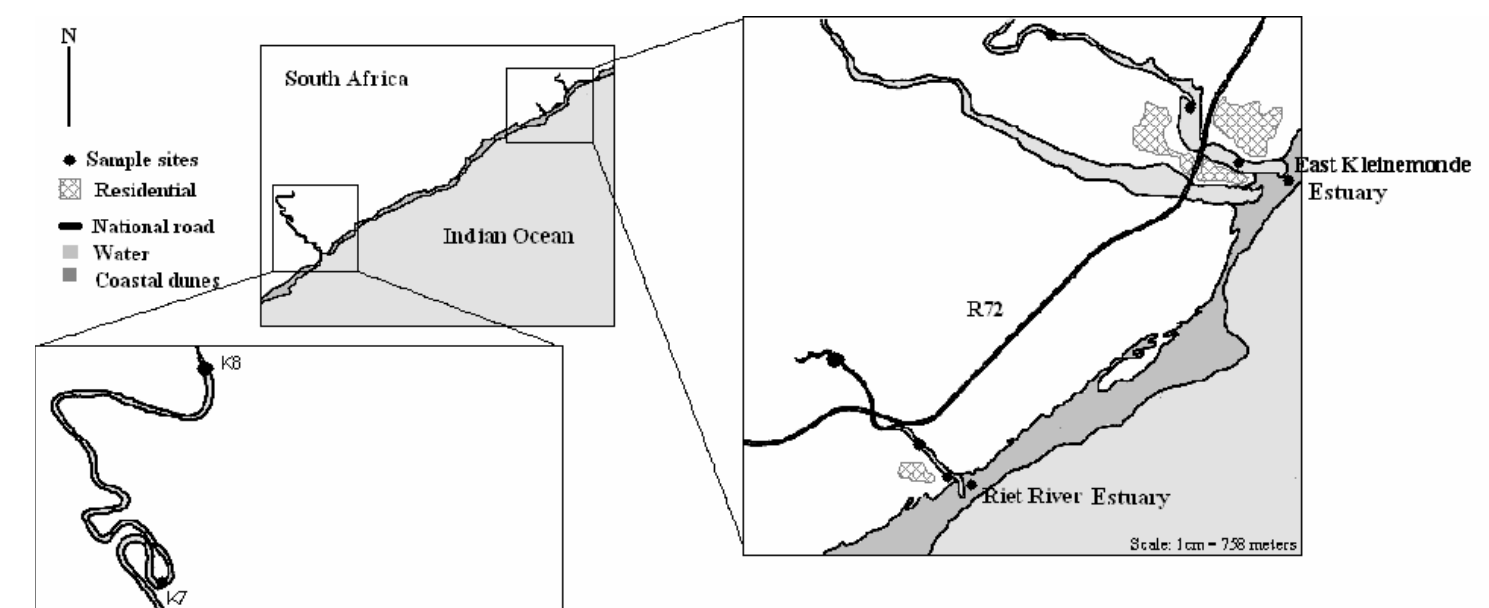

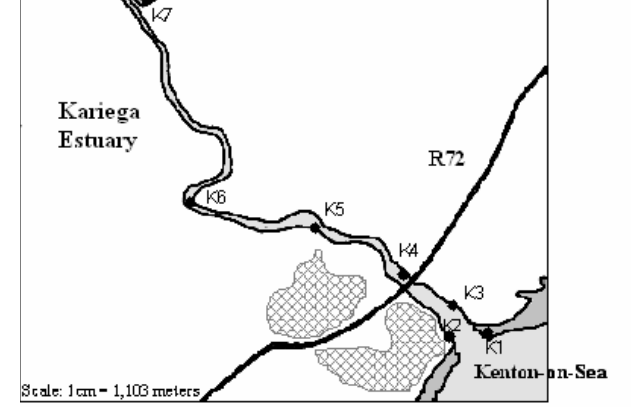

river flow, on the concentrations and enrichment of metals in the sediment and water column of three Eastern Cape estuaries, namely, the Kariega, the Riet and the East Kleinemonde Estuaries. Reduced freshwater inflow is a factor which may contribute to the accumulation of metals within an estuary, and increases in river-inflow may in turn dilute contaminants and/or flush them from the estuary (Ruiz and Saiz-Salinas, 2000). Temporal variations in metal concentrations are theoretically related to river flow processes, but practical evidence for such effects is scarce (Ruiz and Saiz-Salinas, 2000). It is thus important to conduct flow-related studies on metal enrichment, especially in flowrestricted estuaries such as the Kariega.

\section{Materials and methods}

\section{Study area}

The Kariega, Riet and East Kleinemonde Estuaries are situated on the warm-temperate south-east coast of South Africa (Fig. 1). According to Harrison et al. (2000) the three estuaries are considered to be in 'good' ecological condition.

The Kariega Estuary (3340'42'S; $26^{\circ} 40^{\prime} 51^{\prime} \mathrm{E}$ ) is a permanently open system that is $\sim 18 \mathrm{~km}$ in length and is situated approximately mid-way between the coastal cities of Port Elizabeth and East London. The estuary connects to the sea on the north-eastern side of the coastal resort town, Kenton-on-Sea. A road running from East London to Port Elizabeth (R72) crosses the estuary approximately $1 \mathrm{~km}$ from the mouth, and residential and holiday developments are primarily situated along the lower reaches and near the mouth of the estuary. There is no industrialisation along the estuary, but several stormwater drains discharge into the Kariega, the largest of which is located near the mouth (Jennings, 2005). The Kariega receives a negligible annual inflow of freshwater $\left(\sim 15 \times 10^{6} \mathrm{~m}^{3}\right)$ and is typically described as being a marine-dominated system that is homogeneous with respect to its salinity (Grange and Allanson, 1995). The limited and sporadic input of freshwater into the system can be attributed to the arid climate of the Eastern Cape, the small size of the catchment $\left(686 \mathrm{~km}^{2}\right)$, and most importantly three large dams and numerous weirs within the catchment that impound runoff (Bate et al., 2002). The upper reaches of the estuary are often hypersaline, and only during periods of sustained heavy rainfall has a decreasing salinity gradient been observed from the mouth to the upper reaches.

The East Kleinemonde Estuary ( $\left.33^{\circ} 32^{\prime} 21^{\prime \prime} \mathrm{S} ; 2^{\circ} 02^{\prime} 55^{\prime \prime} \mathrm{E}\right)$ is a medium-sized temporary open/closed system that is situated approximately $40 \mathrm{~km}$ north-east of the Kariega Estuary. The R72 crosses the estuary $\sim 500 \mathrm{~m}$ from the mouth, and the lower reaches of the estuary are surrounded by residential and holiday houses. There is little development in the upper reaches of the East Kleinemonde. The estuary is $\sim 3.5 \mathrm{~km}$ long, has a catchment size of 46.3 $\mathrm{km}^{2}$ and a mean annual runoff of $2 \times 10^{6} \mathrm{~m}^{3}$ (Badenhorst, 1998).

The Riet Estuary $\left(33^{\circ} 33^{\prime} 40^{\prime \prime} \mathrm{S} ; 2^{\circ} 00^{\prime} 53^{\prime \prime} \mathrm{E}\right)$ is a small temporary open/closed system situated $\sim 10 \mathrm{~km}$ north east of the coastal town of Port Alfred and approximately $33 \mathrm{~km}$ north east of the Kariega Estuary. The only developments along the banks of the estuary are residential and holiday cottages, which occupy a small area of the surroundings. The R72 crosses the estuary $\sim 1.2 \mathrm{~km}$ from the mouth.

\section{Sampling}

Eight sites were sampled in the Kariega Estuary and four in each of the Riet and East Kleinemonde Estuaries (Fig. 1). Sampling sites were chosen to represent conditions in the mouth and lower, middle and upper reaches of each system. The Kariega Estuary was sampled during the dry (July 2006) and wet season (November 2006), and the East Kleinemonde (May 2006 and September 2006) and the Riet (June 2006 and October 2006) during open and closed mouth phases. Heavy rainfall within the catchment contributed to the formation of an axial gradient in salinity in the Kariega Estuary for the first time in 10 years. Similarly, the high rainfall resulted in the breaching of the East Kleinemonde and Riet Estuaries. 
Prior to the collection of samples, glass sampling bottles were pre-cleaned by soaking in 5 to $10 \% \mathrm{HNO}_{3}$ (55\%, chemically pure, Merck Chemicals) for $24 \mathrm{~h}$, and then rinsed thoroughly with deionised water. Approximately $1 \ell$ of estuarine/ marine surface water was collected and preserved by lowering the $\mathrm{pH}$ to below 2 with concentrated $\mathrm{HNO}_{3}$. The samples were transported to the laboratory and stored at $2^{\circ} \mathrm{C}$ prior to extraction and analysis. Surface sediment samples were collected from the shore edge of the estuary with a plastic scoop and were placed in clean, airtight, plastic Ziploc ${ }^{\circledR}$ bags and transported to the laboratory and stored at $2^{\circ} \mathrm{C}$ until further processing. Three replicate water and sediment samples were collected at each site, each sample analysed individually.

\section{Analysis of water samples}

A liquid-liquid extraction method using ammonium pyrrolidine dithiocarbamate (APDC) and methyl isobulyl ketone (MIBK) was used for the analysis of $\mathrm{Pb}$ and $\mathrm{Cd}$ in water samples (Brooks et al., 1967; Standard Methods, 1998). Exactly $750 \mathrm{~m} \ell$ of water sample was adjusted to a $\mathrm{pH}$ of 3 to 4 by the addition of $4 \mathrm{M}$ $\mathrm{NaOH}$ (pellets, $98 \% \mathrm{~m}$ Merck Chemicals) and/or $4 \mathrm{M} \mathrm{HNO}_{3}$ (55\%, chemically pure, Merck Chemicals) and placed in $1 \ell$ glass volumetric flasks. A $1 \%$ solution (w/v) of APDC ( $>98.0 \%$, purum p.a., Sigma-Aldrich) was prepared daily and purified by shaking with $50 \mathrm{~m} \ell$ MIBK ( $>99 \%$, spectrophotometric grade, Sigma-Aldrich). A $7 \mathrm{m \ell}$ aliquot of a $1 \%$ solution of APDC was added to each sample and briefly shaken, after which $35 \mathrm{ml}$ of MIBK was added and the samples shaken for $10 \mathrm{~min}$ at 150 $\mathrm{r} \cdot \mathrm{min}^{-1}$ on a mechanical shaker (Brooks et al., 1967). The phases were allowed to fully separate. Deionised water was carefully added to the aqueous layer using a funnel so that the organic layer was raised into the neck of the volumetric flask (Standard Methods, 1998). The organic layer was removed and stored in glass test tubes, in the dark, at $2^{\circ} \mathrm{C}$ until analysis.

Laboratory blanks were prepared from deionised water and extracted in the same manner as samples (Standard Methods, 1998). Calibration standards were prepared by adding incremental volumes of $50 \mathrm{mg} \cdot \ell^{-1}$ solution of $\mathrm{Cd}$ and $\mathrm{Pb}$ to $750 \mathrm{~m} \ell$ deionised water to make 12 to 15 multi-element standards that covered the concentration range of 1 to $25 \mu \mathrm{g} \cdot \ell^{-1}$. The standards were extracted in the same manner as samples. Calibration standards, blanks and samples were aspirated into a fuel-lean air-acetylene flame of the atomic absorption spectrophotometer. The atomiser was rinsed between samples with water-saturated MIBK.

The solubility of MIBK in aqueous solutions decreases as the salinity increases, and thus to correct for the different volumes of MIBK obtained when metals were extracted from samples of different salinities the concentrations obtained by FAAS were multiplied by specific correction factors (Table 1). The correction factors were calculated from MIBK solubility data presented by Kanai et al. (1979). The concentrations of metals in the water column were compared to the target values for South African coastal waters as published in the South African Water Quality Guidelines for Coastal Marine Waters (DWAF, 1995).

\section{Analysis of sediment samples}

Sediment samples for the analysis of $\mathrm{Cd}, \mathrm{Cu}, \mathrm{Pb}, \mathrm{Zn}, \mathrm{Ni}$, Co and Fe were acid digested according to US-EPA method 3050B (US-EPA, 1996). Although this is a strong acid digestion technique, it does not result in a total digestion of sediments and

\begin{tabular}{|c|c|}
\hline \multicolumn{2}{|c|}{ TABLE 1 } \\
$\begin{array}{c}\text { Correction factors used to } \\
\text { adjust the concentrations of } \\
\text { metals in estuarine and seawa- } \\
\text { ter samples of varying salinities }\end{array}$ \\
\hline Salinity (PSU) & Correction factor \\
\hline 0 & 1.00 \\
\hline$<3.6$ & 1.00 \\
\hline 8.3 & 1.22 \\
\hline 16.6 & 1.26 \\
\hline 25.3 & 1.35 \\
\hline 33.4 & 1.40 \\
\hline
\end{tabular}

metals bound to silicates are not therefore released (US-EPA, 1996). Approximately $1 \mathrm{~g}$ of dry, homogenised sediment was refluxed at $90 \pm 10^{\circ} \mathrm{C}$ with a $\mathrm{HNO}_{3}-\mathrm{HCl}-\mathrm{H}_{2} \mathrm{O}_{2}$ acid-peroxide mixture (reagents from Merck Chemicals; $\mathrm{HNO}_{3}$ : $55 \%$, $\mathrm{HCl}$ : $\left.32 \%, \mathrm{H}_{2} \mathrm{O}_{2}: 30 \%\right)$ to release metals into solution (US-EPA, 1996). The digestate was diluted to $50 \mathrm{~m} \ell$ with deionised water and centrifuged at $2500 \mathrm{r} \cdot \mathrm{min}^{-1}$ (Heraeus, Sepatech, Labofuge Ae, Germany) for $10 \mathrm{~min}$ to remove particulates and analysed for metals using flame atomic absorption spectrophotometry (GBC 909 AA, Avanta, Australia) by direct aspiration into an air-acetylene flame. Calibration standards were prepared from $1000 \mathrm{mg} \cdot \ell^{-1}$ standard solutions (EC Labs, South Africa). Method blanks were prepared from the same acids and subjected to the same digestion procedure as the sample.

Total organic content (TOC) of the sediments was determined by the loss-on-ignition method (Schumacher, 2002). Sediment samples were heated at 400 to $450^{\circ} \mathrm{C}$ for $24 \mathrm{~h}$ in ceramic crucibles, and TOC determined as the mass of weight lost over the initial weight of the sediment. The grain size distribution of sediments was estimated by a combination of wet and dry sieve methods. The percentage clay and silt content was determined by soaking a known weight of dry sediment in $250 \mathrm{~m} \ell$ water and $10 \mathrm{~m} \ell$ sodium hexametaphosphate $\left(6.2 \mathrm{~g} \cdot \ell^{-1}\right.$, practical grade, Sigma-Aldrich) for at least $2 \mathrm{~h}$, after which the slurry was passed through a $63 \mu \mathrm{m}$ sieve. The sand fraction remaining in the sieve was dried at $60^{\circ} \mathrm{C}$ for $24 \mathrm{~h}$ and weighed. The mud fraction was determined by the difference in weights before and after wet sieving. The size distribution of the remaining sand fraction was determined by dry sieving the sand through a nest of sieves that was mechanically shaken for $10 \mathrm{~min}$.

In the absence of sediment quality guidelines (SQGs) for South African estuarine and coastal sediments (Newman and Watling, 2007), it was decided that there are no suitable SQGs that could be used to screen sediment concentrations in this study.

\section{Geochemical normalisation and enrichment factors}

High total concentrations of metals in sediment do not necessarily indicate input of metals from human activities, as elevated levels of metals may be a result of variations in sediment characteristics as well as naturally high background concentrations (Schropp et al., 1990; Liu et al., 2003). Many factors affect the concentrations of metals in sediment, such as grain size, TOC and mineralogy. In natural, uncontaminated sediments, metal concentrations tend to increase as grain size decreases, due to the fact that mud is comprised predominantly of metal-bearing aluminosilicates, while sand is comprised predominantly of metal-poor quartz (Summers et al., 1996; Schropp et al., 1990). Total organic carbon acts as a matrix to which metals can 
complex, and several studies have shown strong linear relationships between TOC and metal concentrations (Daskalakis and O’Connor, 1995; Tam an Yao, 1998).

Since grain size, TOC and mineralogy vary along the length of an estuary, one cannot simply use high absolute concentrations of metals as an indicator for anthropogenic metal contamination. Metal concentrations are thus commonly normalised to a grain-size parameter or a suitable substitute for grain size, and only then can the correct interpretation of sediment metal concentrations be made (Summers et al., 1996). Various constituents of the sediment may be used to normalise metal concentrations, including $\mathrm{Al}, \mathrm{Fe}$ and total organic carbon. Iron is commonly used as a proxy for grain size effects on metal concentrations for the following reasons: it ubiquitously coats sediment and is thus proportional to the surface area of the sediment (Gibbs, 1994); it is abundant in the earth's crust and is not likely to have a significant anthropogenic source (Gibbs, 1994; Summers et al., 1996); and ratios of metal concentrations to Fe concentrations are relatively constant in the earths crust (Summers et al., 1996). Normalised metal/Fe ratios can thus be used to estimate the extent of metal contamination within an estuary, and to assess whether there has been enrichment of metals from anthropogenic activities.

In uncontaminated sediments strong linear relationships typically exist between Fe and metal concentrations (Schropp et al., 1990; Summers et al., 1996). Simple linear regression models can thus be developed to explain background metal vs. Fe relationships, and these can then be used to assess enrichment of metals in sediment relative to natural concentrations. These models should be developed from a large regional database of uncontaminated sediments, and would thus be applicable to a variety of sediments (Summers et al., 1996). Ideally the sediments used in the baseline model should also cover a full grain-size distribution and thus yield a wide range of Fe concentrations (Summers et al, 1996). Data points may then be superimposed on the baseline regression models, and if the points fall within the 95\% prediction limits of the model, the sediments are considered to be uncontaminated (Tam and Yao, 1998; Schropp et al., 1990; Summers et al., 1996). Data points that fall above the upper $95 \%$ prediction limit are identified as metal enriched (Liu et al., 2003). Caution should be exercised when using this method as a finding of enrichment is not always an indication of anthropogenic contamination (Schropp et al., 1990). Metals may exceed the upper 95\% prediction limit due to procedural errors (such as contamination during sampling) or due to the probability that a few samples from uncontaminated areas exceed the 95\% prediction limit (Schropp et al., 1990).

In this study Fe has been used as a reference element for normalising metal concentrations. Baseline regression models have been developed from regional metal concentrations reported during the early 1980s (Watling and Watling, 1983).

\section{Development of baseline linear regression models}

Simple linear regression models were developed by plotting baseline concentrations of $\mathrm{Cd}, \mathrm{Co}, \mathrm{Cu}, \mathrm{Ni}, \mathrm{Pb}$ and $\mathrm{Zn}$ against baseline Fe concentrations. The baseline concentrations used were those published by Watling and Watling (1983) for surface and core sediments from the Bushmans, Kariega, Kowie and Great Fish Rivers. Any samples that were anthropogenically enriched with metals should be removed from the baseline data set (Schropp et al., 1990; Summers et al., 1996). The baseline data were thus examined for statistical outliers and influential cases using residual plots and Cook's distance test (Summers et al., 1996). Data points with a standard residual greater than $2 *$ standard deviation were removed prior to performing the final regression analysis. Simple linear regression plots of each metal vs. Fe were constructed using the resulting data set (Summers et al., 1996). The concentrations of metals in sediments from this study were then superimposed onto the baseline regression plots, and data points that fell above the upper 95\% prediction limit of the baseline models were identified as being enriched (Schropp et al., 1990).

\section{Enrichment factors}

Regression models were used to predict what metal concentrations would be obtained at the upper 95\% prediction limit for given (sample) Fe concentrations. Metal enrichment within surface sediments was then quantified by dividing the measured concentration by the concentration predicted by the baseline regression model. Thus, enrichment factor $(\mathrm{EF})=\mathrm{M}_{\text {observed }} /$ $M_{\text {predicted }}$ where $\mathrm{M}=$ metal concentration (Roach et al. 2005). For $\mathrm{Cd}$, the EF was calculated by dividing the measured concentration by the highest regional baseline concentration above which enrichment can be inferred (Roach, 2005). This concentration was calculated to be $0.360 \mu \mathrm{g} \cdot \mathrm{g}^{-1} \mathrm{Cd}$ by Newman and Watling (2007).

\section{Quality assurance}

The percentage recovery of metals from the sediment was determined by digesting National Institute of Standards and Technology (NIST) certified reference estuarine sediment No. 1646a. The spiking method was used to determine the percentage recovery of metals from water samples (EURACHEM, 1998). Seawater samples were spiked with $50 \mathrm{mg} \cdot \ell^{-1} \mathrm{~Pb}$ and $\mathrm{Cd}$ to give concentrations of $5 \mu \mathrm{g} \cdot \ell^{-1}$ and $10 \mu \mathrm{g} \cdot \ell^{-1}$. The spiked samples were subjected to the same extraction procedure as that adopted for the analysis of metals in seawater. The spiking of seawater samples was repeated six times at each concentration, and the average percentage recoveries were determined for each concentration.

\section{Statistical analysis}

Data were analysed for temporal variations in metal concentrations using a t-test for independent samples. Data that were not normally distributed were analysed using the non-parametric Mann-Whitney U Test. Data were examined for spatial variations using one-way ANOVA. To measure the relationship between sediment characteristics and metal concentrations, Spearman's Rank Order Correlation was used (Chen et al., 2007).

\section{Results and discussion}

Linear regression analysis of baseline data published by Watling and Watling (1983) revealed that all metals except Cd exhibit significant linear relationships with $\mathrm{Fe}(\mathrm{p}<0.05$; Fig. 2). Once data were superimposed onto metal-Fe baseline models it was possible to determine at which sites metal concentrations were elevated above baseline concentrations (Figs. 3, 7 and 9).

\section{Kariega Estuary}

The mean concentrations of metals in the Kariega Estuary sediment are presented in Table 2. The average sediment concentrations of $\mathrm{Co}$ and $\mathrm{Pb}$ were significantly lower during the wet 

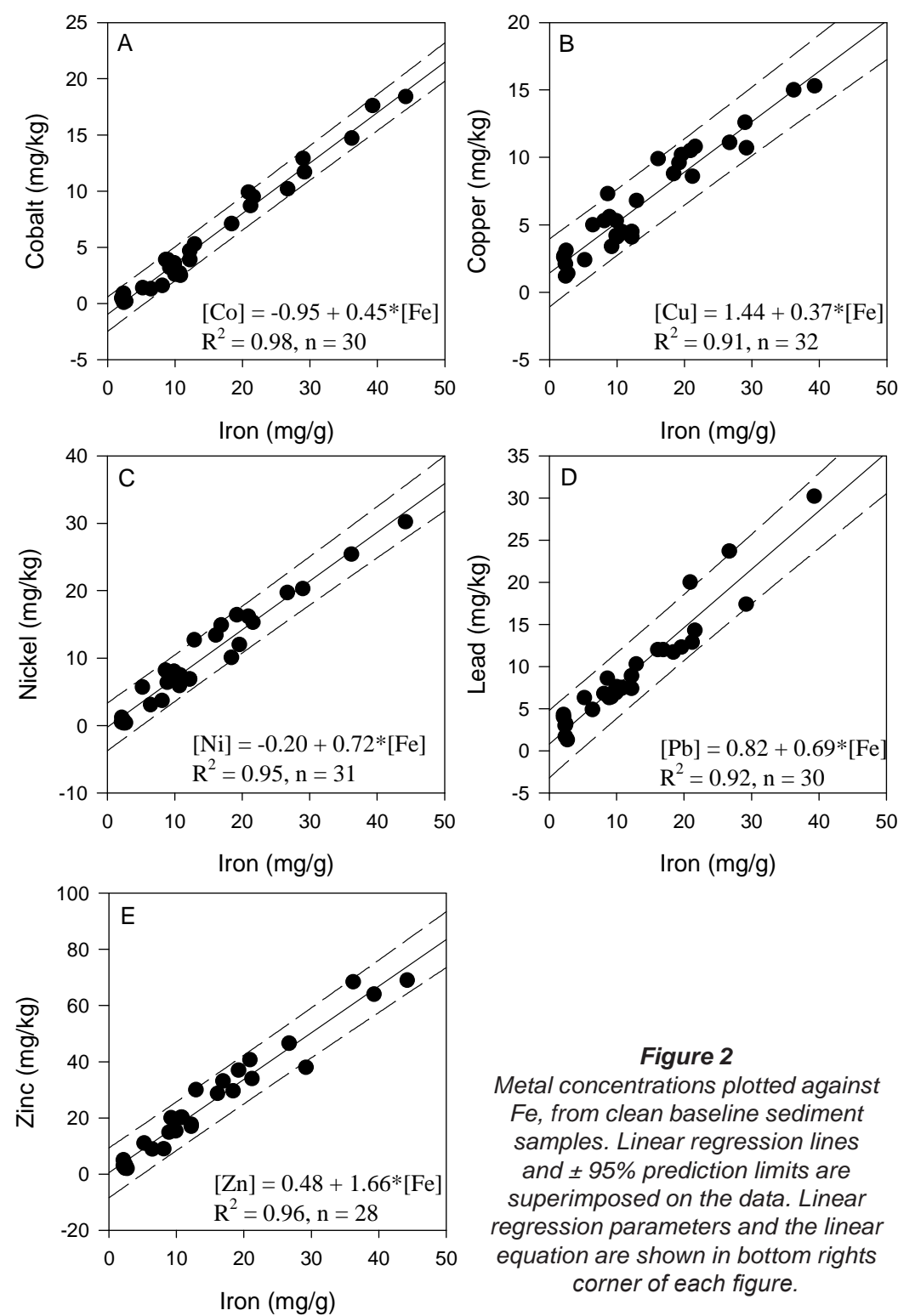

Metal concentrations plotted against Fe, from clean baseline sediment samples. Linear regression lines and $\pm 95 \%$ prediction limits are superimposed on the data. Linear regression parameters and the linear equation are shown in bottom rights corner of each figure. season $(p<0.05)$, and the average sediment concentration of $\mathrm{Cd}$ was significantly higher $(p<0.05)$. During the wet season the mean $\mathrm{Cd}$ concentration was above the regional baseline concentration of $0.360 \mu \mathrm{g} \cdot \mathrm{g}^{-1}$ above which enrichment can be suspected. These variations in absolute concentrations may have been due to variations in grain size between seasons, and thus enrichment factors were calculated that normalised metal concentrations for grain size.

During both dry and wet periods, the metals that showed the most extensive enrichment were $\mathrm{Co}, \mathrm{Ni}$ and $\mathrm{Pb}$ (Figs. 3A, 3C and 3D). During the dry season samples from all sites within the Kariega Estuary fell above the upper 95\% prediction limit of the regression model for Co (Fig. 3A), while during the wet season fewer samples fell above this limit. Five samples were enriched with $\mathrm{Cu}$ during the dry season, and no $\mathrm{Cu}$ enrichment was evident in the sediment of the Kariega Estuary during the wet season (Fig. 3B). Sediment samples were enriched with Ni during both dry and wet seasons, but the enrichment was more evident during the dry season with the majority of samples falling above the upper 95\% prediction limit. The bulk of sediment samples were enriched with $\mathrm{Pb}$ during the dry season and fewer samples were enriched with $\mathrm{Pb}$ during the wet season (Fig. 3D). There were very few samples that fell above the 95\% prediction limit for Zn during both seasons. There thus appears to be more extensive enrichment of $\mathrm{Pb}, \mathrm{Cu}, \mathrm{Co}$ and $\mathrm{Ni}$ above background concentrations during July (dry season) as compared to November (wet season) within the Kariega Estuary.

Figure 4 shows the spatial variation in enrichment factors (EFs) for metals in the Kariega Estuary sediments during July and

\begin{tabular}{|c|c|c|c|c|c|c|c|c|}
\hline \multicolumn{9}{|c|}{$\begin{array}{c}\text { TABLE } 2 \\
\text { Mean ( } \pm \text { SD) absolute concentrations (mg/kg, dry wt) of all metals measured in sediments from the } \\
\text { Kariega, East Kleinemonde and Riet Estuaries, sampled during dry and wet seasons }\end{array}$} \\
\hline Estuary & Season & $\mathrm{Cd}$ & Co & $\mathrm{Cu}$ & $\mathrm{Fe}$ & $\mathrm{Ni}$ & $\mathrm{Pb}$ & $\mathrm{Zn}$ \\
\hline \multirow[t]{2}{*}{ Kariega } & Dry & $\begin{array}{c}0.35^{*} \\
( \pm 0.29) \\
\end{array}$ & $\begin{array}{c}5.59 * \\
( \pm 1.92) \\
\end{array}$ & $\begin{array}{c}3.48 \\
( \pm 4.34) \\
\end{array}$ & $\begin{array}{c}5541 \\
( \pm 6360) \\
\end{array}$ & $\begin{array}{c}10.38( \pm \\
6.27) \\
\end{array}$ & $\begin{array}{l}22.65^{*} \\
( \pm 3.36) \\
\end{array}$ & $\begin{array}{c}15.21 \\
( \pm 22.34) \\
\end{array}$ \\
\hline & Wet & $\begin{array}{c}1.22^{*} \\
( \pm 2.11)\end{array}$ & $\begin{array}{c}4.33^{*} \\
( \pm 1.76) \\
\end{array}$ & $\begin{array}{c}3.36 \\
( \pm 2.11) \\
\end{array}$ & $\begin{array}{c}4634 \\
( \pm 4996) \\
\end{array}$ & $\begin{array}{c}10.28 \\
( \pm 18.17) \\
\end{array}$ & $\begin{array}{l}14.09^{*} \\
( \pm 7.44) \\
\end{array}$ & $\begin{array}{c}16.97 \\
( \pm 28.76) \\
\end{array}$ \\
\hline \multirow[t]{2}{*}{ East Kleinemonde } & $\begin{array}{l}\text { Closed mouth } \\
\text { (dry) }\end{array}$ & $\begin{array}{c}1.42 \\
( \pm 0.83) \\
\end{array}$ & $\begin{array}{c}6.24 \\
( \pm 3.64) \\
\end{array}$ & $\begin{array}{c}4.56 \\
( \pm 3.30) \\
\end{array}$ & $\begin{array}{c}8554^{* *} \\
( \pm 1053)\end{array}$ & $\begin{array}{c}11.84 \\
( \pm 5.34) \\
\end{array}$ & $\begin{array}{c}21.91 \\
( \pm 8.27)\end{array}$ & $\begin{array}{l}21.75 * * \\
( \pm 20.31) \\
\end{array}$ \\
\hline & $\begin{array}{l}\text { Open mouth } \\
\text { (wet) }\end{array}$ & $\begin{array}{c}1.19 \\
( \pm 1.16)\end{array}$ & $\begin{array}{c}5.26 \\
( \pm 0.73) \\
\end{array}$ & - & $\begin{array}{l}2248 * * \\
( \pm 1246)\end{array}$ & $\begin{array}{c}10.69 \\
( \pm 10.99)\end{array}$ & $\begin{array}{c}21.71 \\
( \pm 7.44)\end{array}$ & $\begin{array}{c}5.77 * * \\
( \pm 12.22) \\
\end{array}$ \\
\hline \multirow[t]{2}{*}{ Riet } & \begin{tabular}{|l|}
$\begin{array}{l}\text { Closed mouth } \\
\text { (dry) }\end{array}$ \\
\end{tabular} & $\begin{array}{c}0.81 \\
( \pm 0.47)\end{array}$ & $\begin{array}{c}3.29 \\
( \pm 1.93)\end{array}$ & $\begin{array}{c}3.44 \\
( \pm 2.26) \\
\end{array}$ & $\begin{array}{c}2119 \\
( \pm 1030)\end{array}$ & $\begin{array}{c}6.31^{\bullet} \\
( \pm 3.86)\end{array}$ & $\begin{array}{c}11.96 \\
( \pm 5.94)\end{array}$ & $\begin{array}{c}6.26 \\
( \pm 10.71)\end{array}$ \\
\hline & $\begin{array}{l}\text { Open mouth } \\
\text { (wet) }\end{array}$ & $\begin{array}{c}1.21 \\
( \pm 1.17)\end{array}$ & $\begin{array}{c}3.34 \\
( \pm 1.21)\end{array}$ & $\begin{array}{c}2.74 \\
( \pm 2.79)\end{array}$ & $\begin{array}{c}3634 \\
( \pm 2877)\end{array}$ & $\begin{array}{c}9.92^{\bullet} \\
( \pm 2.56)\end{array}$ & $\begin{array}{c}12.39 \\
( \pm 4.71)\end{array}$ & $\begin{array}{c}9.25 \\
( \pm 8.78)\end{array}$ \\
\hline${ }^{1}$ Kariega 1983 & & 0.05 & 5.4 & 7.5 & 16050 & 9.9 & 10.7 & 27.1 \\
\hline
\end{tabular}


November. Cobalt and $\mathrm{Pb}$ enrichment increased significantly $(\mathrm{P}<0.05)$ in a seaward direction during both seasons (Figs. 4B and 4E). In November $\mathrm{Pb}$ enrichment was significantly higher at site K2 $(\mathrm{p}<0.05)$, which was situated directly below a storm water drain. Lead is likely to have entered the estuary at this site via runoff from surrounding roads and parking lots. There
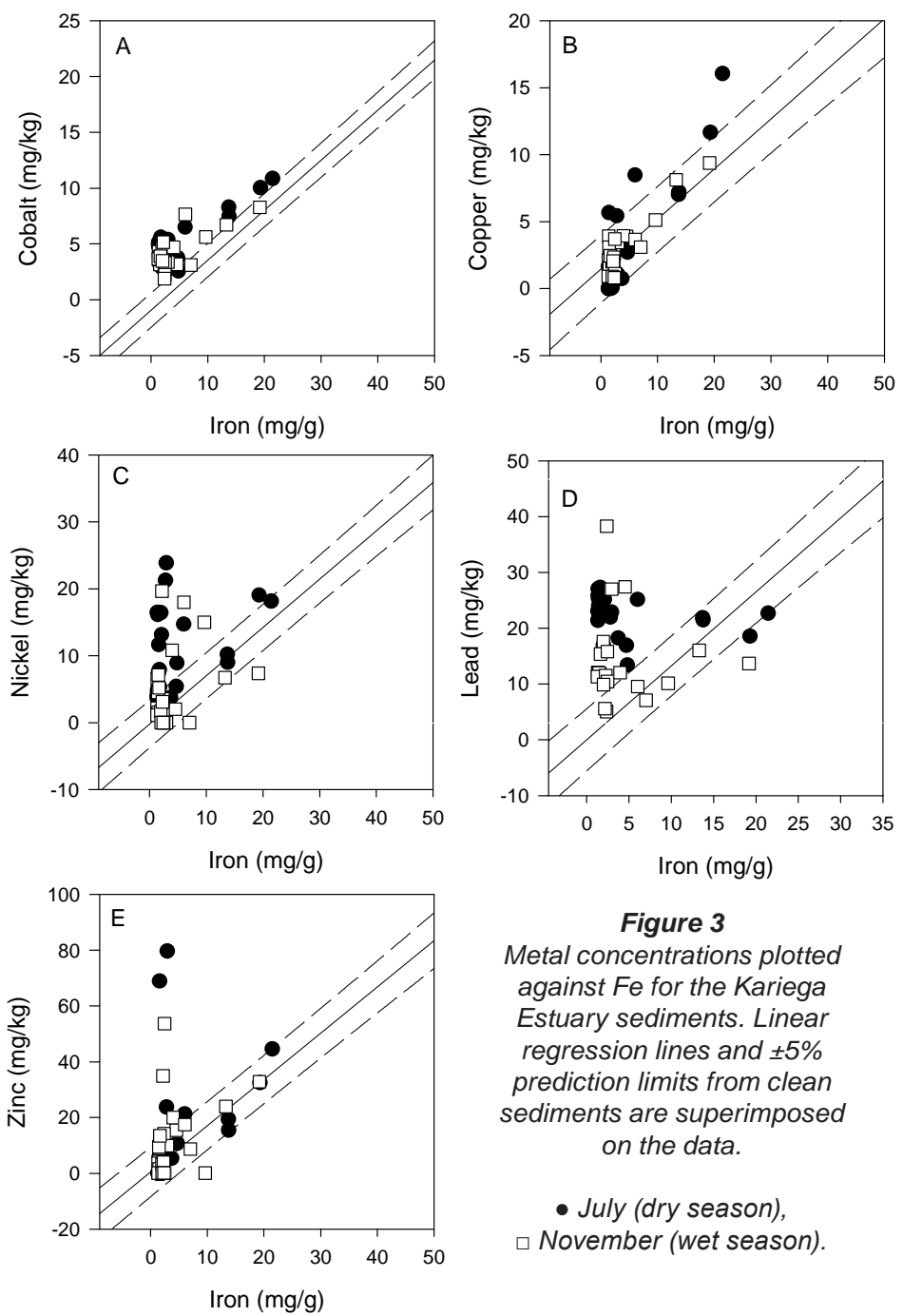

was no significant spatial variation in $\mathrm{Cu}$ and $\mathrm{Ni}$ enrichment during both the dry and wet seasons (Fig. 4C and 4D). There was no significant variation in Zn enrichment along the Kariega Estuary during the dry season (Fig. 4F). Seven out of the 8 sites along the Kariega Estuary showed no significant spatial variation in $\mathrm{Zn}$ concentration during the wet season, however, site K5 was significantly more enriched $(\mathrm{p}<0.05)$ with $\mathrm{Zn}$ than all other sites (Fig. 4F). This anomalously high peak in Zn enrichment may be due to sample contamination during processing. Cadmium enrichment was significantly higher in the mouth-to-middle reaches of the estuary during the dry season and showed no significant spatial variation during the wet season (Fig. 6A). It is interesting to note that the enrichment factors for $\mathrm{Co}, \mathrm{Ni}$ and $\mathrm{Pb}$ were generally higher during the dry season at sites K1-K5 than during the wet season. This suggests that these metals were scoured from the surface sediments of the estuary during the period of heavy rainfall, via erosion.

Table 3 shows the average enrichment factors (EFs) for the Kariega Estuary during July and November. Enrichment factors for $\mathrm{Co}, \mathrm{Ni}$ and $\mathrm{Pb}$ were significantly higher in July (dry season) than in November (wet season) $(p<0.05)$. There was no significant difference in enrichment factors for $\mathrm{Cd}$, $\mathrm{Cu}$ and $\mathrm{Zn}$ between July and November $(\mathrm{p}<0.05)$, however there was a noticeable increase in the average $\mathrm{Cd}$ enrichment during the wet season. Enrichment factors for $\mathrm{Pb}, \mathrm{Co}$ and $\mathrm{Ni}$ were greater than 1 during the dry season indicating enrichment relative to baseline concentrations. Samples obtained during the wet season had EFs $>1$ for $\mathrm{Pb}, \mathrm{Co}, \mathrm{Ni}$ and $\mathrm{Cd}$.

Both TOC content and grain size were important factors controlling the distribution of select metals in the sediment of the Kariega Estuary. Significant negative correlations existed between the medium-to-fine sand fraction and the concentrations of the majority of metals in both July and November. This relationship has also been observed in other estuaries (Chen et al., 2007). During the

\begin{tabular}{|c|c|c|c|c|c|c|c|}
\hline \multicolumn{8}{|c|}{$\begin{array}{c}\text { TABLE } 3 \\
\text { Mean ( } \pm \text { SD) enrichment factors (EF) for sediments from the Kariega, East Kleinemonde } \\
\text { and Riet Estuaries, sampled during dry and wet seasons }\end{array}$} \\
\hline Estuary & Season & Cd & Co & $\mathrm{Cu}$ & $\mathrm{Ni}$ & $\mathrm{Pb}$ & $\mathrm{Zn}$ \\
\hline \multirow[t]{2}{*}{ Kariega } & Dry & $\begin{array}{c}0.75 \\
( \pm 0.65)\end{array}$ & $\begin{array}{c}2.71^{*} \\
( \pm 1.21)\end{array}$ & $\begin{array}{c}0.52 \\
( \pm 0.43)\end{array}$ & $\begin{array}{c}1.66^{*} \\
( \pm 1.13)\end{array}$ & $\begin{array}{c}3.17^{*} \\
( \pm 1.17)\end{array}$ & $\begin{array}{c}0.65 \\
( \pm 1.12) \\
\end{array}$ \\
\hline & Wet & $\begin{array}{c}2.82 \\
( \pm 4.86)\end{array}$ & $\begin{array}{c}2.02 * \\
( \pm 0.83)\end{array}$ & $\begin{array}{c}0.58 \\
( \pm 0.28)\end{array}$ & $\begin{array}{c}1.36^{*} \\
( \pm 2.14) \\
\end{array}$ & $\begin{array}{c}1.96 * \\
( \pm 1.19) \\
\end{array}$ & $\begin{array}{c}0.87 \\
( \pm 1.05) \\
\end{array}$ \\
\hline \multirow[t]{2}{*}{$\begin{array}{l}\text { East } \\
\text { Kleinemonde }\end{array}$} & \begin{tabular}{|l|}
$\begin{array}{l}\text { Closed mouth } \\
\text { (dry) }\end{array}$ \\
\end{tabular} & $\begin{array}{c}3.28 \\
( \pm 1.92)\end{array}$ & $\begin{array}{l}\text { 2.07** } \\
( \pm 1.21)\end{array}$ & $\begin{array}{c}0.64^{* *} \\
( \pm 0.38)\end{array}$ & $\begin{array}{c}1.81 \\
( \pm 1.29)\end{array}$ & $\begin{array}{c}2.64 \\
( \pm 1.58)\end{array}$ & $\begin{array}{r}0.90 * * \\
( \pm 0.63)\end{array}$ \\
\hline & \begin{tabular}{|l|}
$\begin{array}{l}\text { Open mouth } \\
\text { (wet) }\end{array}$ \\
\end{tabular} & $\begin{array}{c}1.67 \\
( \pm 1.87) \\
\end{array}$ & $\begin{array}{l}3.33 * * \\
( \pm 1.17) \\
\end{array}$ & $\begin{array}{c}0.18 * * \\
( \pm 0.02)\end{array}$ & $\begin{array}{c}1.44 \\
( \pm 0.47)\end{array}$ & $\begin{array}{c}3.41 \\
( \pm 1.53)\end{array}$ & $\begin{array}{c}0.15^{* *} \\
( \pm 0.13) \\
\end{array}$ \\
\hline \multirow[t]{2}{*}{ Riet } & $\begin{array}{l}\text { Closed Mouth } \\
\text { (dry) }\end{array}$ & $\begin{array}{c}2.27 \\
( \pm 1.31) \\
\end{array}$ & $\begin{array}{c}2.14 \\
( \pm 1.42) \\
\end{array}$ & $\begin{array}{c}0.73 \\
( \pm 0.50) \\
\end{array}$ & $\begin{array}{c}0.37^{\bullet} \\
( \pm 0.26) \\
\end{array}$ & $\begin{array}{c}1.94 \\
( \pm 1.02) \\
\end{array}$ & $\begin{array}{c}0.22 \\
( \pm 0.25) \\
\end{array}$ \\
\hline & $\begin{array}{l}\text { Open Mouth } \\
\text { (wet) }\end{array}$ & $\begin{array}{c}4.07 \\
( \pm 3.93)\end{array}$ & $\begin{array}{c}1.96 \\
( \pm 1.27)\end{array}$ & $\begin{array}{c}0.49 \\
( \pm 0.48)\end{array}$ & $\begin{array}{c}1.87^{\bullet} \\
( \pm 0.82)\end{array}$ & $\begin{array}{c}1.55 \\
( \pm 0.90)\end{array}$ & $\begin{array}{c}0.35 \\
( \pm 0.26)\end{array}$ \\
\hline
\end{tabular}



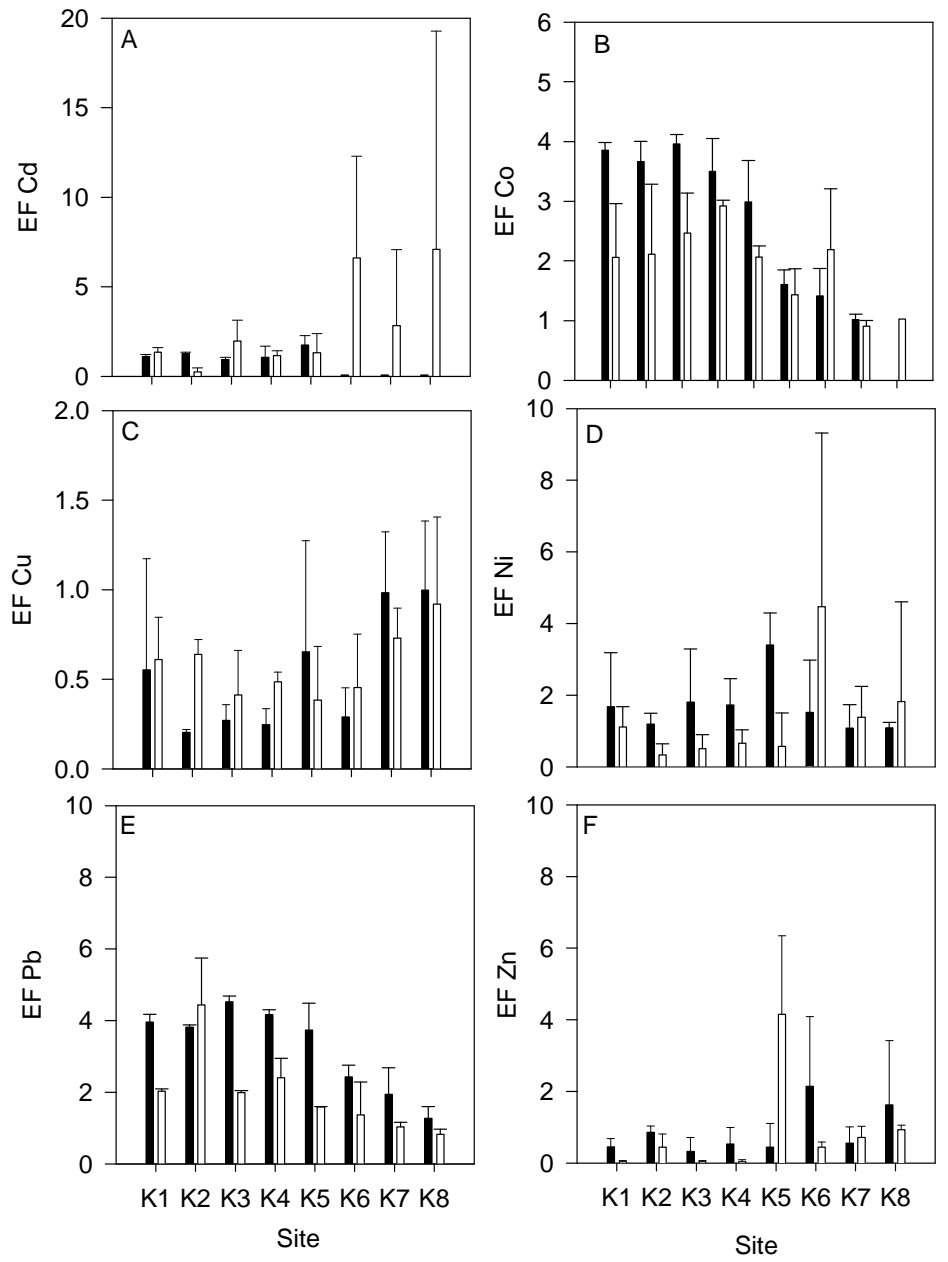

Figure 4

Spatial variation in mean $( \pm S D)$ enrichment factors $(E F)$ for sediments taken from the Kariega Estuary during a dry season and a wet season.

- July (dry season),

$\square$ November (wet season).
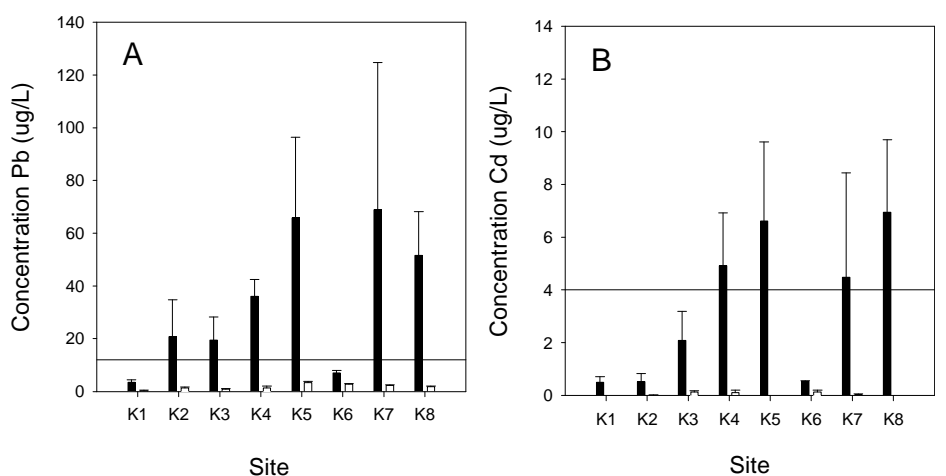

Figure 5

Spatial and temporal variations in the mean concentrations $( \pm S D)$ of $\mathrm{Pb}$ and $\mathrm{Cd}$ in water collected from the Kariega Estuary during a dry season (July) and a wet season (November). Note: Horizontal bar represents South African water quality guidelines for coastal marine waters.

- July (dry season),

$\square$ November (wet season) dry season (July), significant positive correlations were observed between TOC and $\mathrm{Cu}(\mathrm{R}=0.72, \mathrm{p}<0.01)$, Ni ( $\mathrm{R}$ $=0.48, \mathrm{p}<0.05), \mathrm{Fe}(\mathrm{R}=0.91, \mathrm{p}<0.01)$ and $\mathrm{Zn}(\mathrm{R}=0.62$, $\mathrm{p}<0.05)$. Significant positive correlations also existed between the mud fraction (grain size $<0.063 \mu \mathrm{m}$ ) and $\mathrm{Cu}$ $(\mathrm{R}=0.58, \mathrm{p}<0.05)$, Fe $(\mathrm{R}=0.92, \mathrm{p}<0.01)$ and $\mathrm{Zn}(\mathrm{R}=$ $0.67, \mathrm{p}<0.01$ ) during the dry season (Table $4 \mathrm{~A}$ ).

During the wet season $\mathrm{Cu}, \mathrm{Fe}$ and Ni were significantly correlated to both TOC $(\mathrm{R}=0.48, \mathrm{R}=0.0 .78$ and $\mathrm{R}=0.43$, respectively; $\mathrm{p}<0.05)$, and $\mathrm{Cu}$ and Fe were strongly associated with the mud fraction $(\mathrm{R}=0.43, \mathrm{R}=0.85$, respectively; $\mathrm{p}<0.05$ ) (Table $4 \mathrm{~B}$ ). Iron, Ni and $\mathrm{Zn}$ were significantly correlated to $\mathrm{Cu}(\mathrm{R}>0.55, \mathrm{p}<0.01)$ during both seasons. The strong positive correlations between $\mathrm{Fe}$ and the fine grained sediments $(<63 \mu \mathrm{m})$ during both seasons provide evidence that $\mathrm{Fe}$ was an appropriate normaliser for grain size. It is widely accepted that Fe-oxide particles are scavengers for trace metals (Perret et al., 2000), and thus strong correlations between the concentrations of $\mathrm{Fe}$ and other metals may indicate that the metals in question were bound to Fe-oxides.

There was a significant reduction in the net concentrations of $\mathrm{Cd}$ and $\mathrm{Pb}$ in the water of the Kariega Estuary during the wet season $(p<0.05)$. The mean concentration of Cd decreased from $3.323 \pm 4.093 \mu \mathrm{g} \cdot \ell^{-1}$ in the dry season to $0.0503 \pm 0.991 \mu \mathrm{g} \cdot \ell^{-1}$ in the wet season (Fig. 5B), and the mean concentration of $\mathrm{Pb}$ decreased from 34.13 $\pm 42.56 \mu \mathrm{g} \cdot \ell^{-1}$ in the dry season to $1.753 \pm 1.096 \mu \mathrm{g} \cdot \ell^{-1}$ in the wet season (Fig. 5A). Both the mean concentrations of $\mathrm{Cd}$ and $\mathrm{Pb}$ were above the target concentrations $\left(4 \mu \mathrm{g} \cdot \ell^{-1}\right.$ and $12 \mu \mathrm{g} \cdot \ell^{-1}$ respectively) recommended for South African coastal waters (DWAF, 1995). These results suggest that the inflow of freshwater into the Kariega Estuary had the net effect of reducing the concentrations of $\mathrm{Pb}$ and $\mathrm{Cd}$ in the water column by flushing estuarine water to the marine environment, or via dilution with freshwater.

\section{East Kleinemonde Estuary}

Mean $( \pm$ SD) absolute concentrations of metals in the East Kleinemonde sediments during both the dry and wet seasons are presented in Table 2. Zinc and Fe were the only metals that showed a significant change in concentration between the two seasons, with the mean concentration for both decreasing significantly during the wet season $(\mathrm{p}<0.05)$.

Copper and Zn showed almost no enrichment in the East Kleinemonde Estuary, with only a few samples from the dry season falling above the upper 95\% prediction limits of the baseline regression models (Figs. 6B and $6 \mathrm{E})$. Cobalt, $\mathrm{Ni}$ and $\mathrm{Pb}$ enrichment was more extensive when the estuary breached as opposed to when the mouth was closed. This can be seen in Figs. 6A, 6C and 6D in which more samples from the wet season fall above the upper $95 \%$ prediction limits of the corresponding regression models as compared to the dry season. This may suggest that there was an influx of metals flowing into the system during the wet season.

The mean enrichment factors (EFs) for metals from the East Kleinemonde Estuary are shown in Table 3. Cobalt and $\mathrm{Pb}$ enrichment increased during the wet season, while $\mathrm{Cd}, \mathrm{Cu}, \mathrm{Ni}$ and $\mathrm{Zn}$ enrichment decreased. Lead is a common constituent of storm water runoff (Gobel, 2007) and thus it is possible that $\mathrm{Pb}$ enrichment increased 


\begin{tabular}{|c|c|c|c|c|c|c|c|c|c|c|c|c|c|}
\hline \multicolumn{14}{|c|}{$\begin{array}{l}\text { TABLE } 4 \\
\text { A) Spearman rank order correlations for metals concentrations and sediment properties for the Kariega sediments } \\
\text { (dry season) }\end{array}$} \\
\hline & Cd & Co & $\mathrm{Cu}$ & $\mathrm{Fe}$ & $\mathrm{Ni}$ & $\mathrm{Pb}$ & Zn & TOC & $\begin{array}{c}\text { Coarse } \\
\text { sand }\end{array}$ & $\begin{array}{l}\text { Medium } \\
\text { sand }\end{array}$ & $\begin{array}{l}\text { Fine } \\
\text { sand }\end{array}$ & $\begin{array}{l}\text { Very } \\
\text { fine } \\
\text { sand }\end{array}$ & Mud \\
\hline Cd & 1.00 & & & & & & & & & & & & \\
\hline Co & -0.11 & 1.00 & & & & & & & & & & & \\
\hline $\mathrm{Cu}$ & -0.41 & 0.38 & 1.00 & & & & & & & & & & \\
\hline Fe & $-0.53^{*}$ & 0.32 & $0.75^{*}$ & 1.00 & & & & & & & & & \\
\hline $\mathrm{Ni}$ & 0.07 & 0.30 & $0.69 *$ & 0.50 & 1.00 & & & & & & & & \\
\hline $\mathbf{P b}$ & $0.50 *$ & 0.31 & -0.20 & -0.48 & 0.03 & 1.00 & & & & & & & \\
\hline Zn & -0.12 & 0.33 & $0.68 *$ & $0.72 *$ & 0.58* & -0.30 & 1.00 & & & & & & \\
\hline TOC & -0.56 & 0.41 & $0.72 *$ & 0.91* & 0.48 & -0.35 & $0.62 *$ & 1.00 & & & & & \\
\hline Coarse sand & 0.41 & 0.05 & 0.06 & 0.01 & 0.30 & 0.00 & 0.25 & -0.06 & 1.00 & & & & \\
\hline Medium sand & 0.48 & -0.20 & -0.50 & $-0.85^{*}$ & -0.38 & $0.52 *$ & $-0.61 *$ & $-0.90 *$ & 0.30 & 1.00 & & & \\
\hline Fine sand & 0.28 & -0.27 & -0.18 & 0.13 & 0.15 & -0.00 & 0.19 & 0.07 & -0.06 & -0.32 & 1.00 & & \\
\hline Very fine sand & -0.47 & -0.02 & 0.51 & 0.85* & 0.41 & $-0.59 *$ & $0.66 *$ & $0.79 *$ & -0.08 & $-0.87 *$ & 0.46 & 1.00 & \\
\hline Mud & $-0.54 *$ & 0.28 & 0.58* & 0.92* & 0.38 & $-0.58^{*}$ & \begin{tabular}{|l}
$0.67 *$ \\
\end{tabular} & $0.90^{*}$ & -0.07 & $-0.92^{*}$ & 0.11 & $0.85^{*}$ & 1.00 \\
\hline \multicolumn{14}{|c|}{$\begin{array}{l}\text { B) Spearman rank order correlations for metals concentrations and sediment properties for the Kariega sediments } \\
\text { (wet season) }\end{array}$} \\
\hline Cd & 1.00 & & & & & & & & & & & & \\
\hline Co & 0.18 & 1.00 & & & & & & & & & & & \\
\hline $\mathrm{Cu}$ & -0.17 & 0.37 & 1.00 & & & & & & & & & & \\
\hline Fe & -0.48 & \begin{tabular}{|l|}
0.17 \\
\end{tabular} & $0.62 *$ & 1.00 & & & & & & & & & \\
\hline $\mathrm{Ni}$ & 0.47 & 0.49 & $0.60 *$ & 0.21 & 1.00 & & & & & & & & \\
\hline $\mathbf{P b}$ & -0.20 & -0.03 & 0.36 & 0.08 & 0.06 & 1.00 & & & & & & & \\
\hline Zn & 0.15 & 0.21 & $0.62 *$ & 0.41 & $0.66^{*}$ & 0.38 & 1.00 & & & & & & \\
\hline TOC & -0.03 & 0.38 & 0.48 & $0.78 *$ & 0.43 & -0.12 & 0.39 & 1.00 & & & & & \\
\hline Coarse sand & -0.33 & -0.07 & 0.19 & -0.06 & -0.18 & 0.38 & 0.09 & -0.43 & 1.00 & & & & \\
\hline Medium sand & 0.16 & -0.24 & -0.20 & \begin{tabular}{|l}
$-0.68 *$ \\
\end{tabular} & -0.14 & 0.23 & -0.13 & $-0.84^{*}$ & $0.62 *$ & 1.00 & & & \\
\hline Fine sand & 0.37 & -0.12 & $-0.57 *$ & -0.41 & -0.20 & -0.08 & -0.19 & -0.11 & -0.21 & -0.11 & 1.00 & & \\
\hline Very fine sand & -0.22 & -0.00 & 0.18 & 0.71* & 0.17 & -0.42 & 0.13 & 0.73* & \begin{tabular}{|l|}
-0.43 \\
\end{tabular} & \begin{tabular}{|l|}
$-0.78 *$ \\
\end{tabular} & -0.03 & 1.00 & \\
\hline Mud & -0.29 & 0.32 & 0.43 & 0.85* & 0.28 & -0.21 & 0.28 & 0.89* & -0.39 & $-0.89 *$ & -0.19 & 0.87* & 1.00 \\
\hline
\end{tabular}

TABLE 5

A) Spearman rank order correlations (R) for variables measured in the East Kleinemonde sediments (dry season)

\begin{tabular}{|c|c|c|c|c|c|c|c|c|c|c|c|c|c|}
\hline & Cd & Co & $\mathrm{Cu}$ & $\mathrm{Fe}$ & $\mathrm{Ni}$ & $\mathrm{Pb}$ & $\mathrm{Zn}$ & TOC & $\begin{array}{c}\text { Coarse } \\
\text { sand }\end{array}$ & \begin{tabular}{|c|} 
Medium \\
sand
\end{tabular} & $\begin{array}{l}\text { Fine } \\
\text { sand }\end{array}$ & $\begin{array}{l}\text { Very } \\
\text { fine } \\
\text { sand }\end{array}$ & Mud \\
\hline $\mathrm{Cd}$ & & & & & & & & & & & & & \\
\hline Co & & & 1.00 & & & & & & & & & & \\
\hline $\mathrm{Cu}$ & & & 0.60 & 1.00 & & & & & & & & & \\
\hline $\mathrm{Fe}$ & & & 0.26 & 0.52 & 1.00 & & & & & & & & \\
\hline $\mathrm{Ni}$ & & & 0.62 & 0.41 & -0.19 & 1.00 & & & & & & & \\
\hline $\mathrm{Pb}$ & & & 0.62 & 0.41 & -0.29 & $0.81 *$ & 1.00 & & & & & & \\
\hline $\mathrm{Zn}$ & & & 0.44 & $0.82 *$ & 0.71 & -0.01 & 0.10 & 1.00 & & & & & \\
\hline TOC & & & -0.01 & 0.33 & $0.89 *$ & -0.29 & -0.34 & 0.65 & 1.00 & & & & \\
\hline Coarse sand & & & 0.27 & -0.26 & -0.28 & 0.57 & 0.34 & -0.48 & -0.38 & 1.00 & & & \\
\hline Medium sand & & & 0.13 & -0.06 & $-0.79 *$ & 0.37 & 0.62 & -0.29 & $-0.77 *$ & 0.03 & 1.00 & & \\
\hline Fine sand & & & -0.10 & 0.33 & 0.70 & -0.44 & -0.48 & 0.49 & 0.67 & -0.69 & -0.54 & 1.00 & \\
\hline Very fine sand & & & -0.29 & 0.05 & $0.76 *$ & -0.57 & -0.60 & 0.45 & $0.90 *$ & -0.43 & $-0.77 *$ & $0.75^{*}$ & \\
\hline Mud & & & -0.10 & 0.31 & $0.86^{*}$ & -0.48 & -0.53 & 0.62 & $0.85^{*}$ & -0.31 & $-0.87 *$ & 0.59 & 1.00 \\
\hline
\end{tabular}



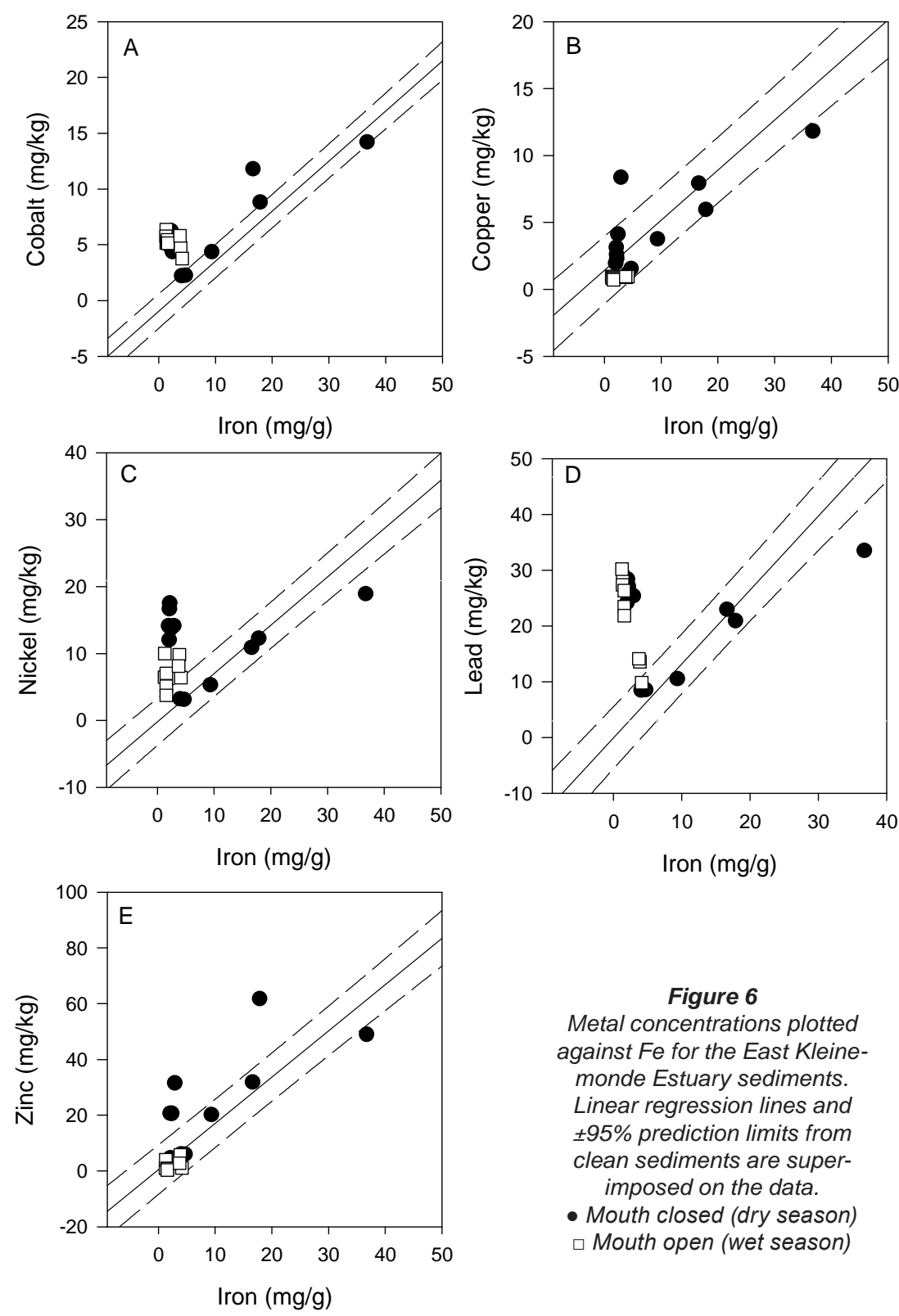

Figure 6

Metal concentrations plotted against Fe for the East Kleinemonde Estuary sediments. Linear regression lines and $\pm 95 \%$ prediction limits from clean sediments are superimposed on the data.

- Mouth closed (dry season)

$\square$ Mouth open (wet season)

during the wet season as a result of increased volumes of runoff entering the estuary. Sediments were not enriched with $\mathrm{Cu}$ and $\mathrm{Zn}$ during both seasons since their enrichment factors were less than 1. Cadmium, $\mathrm{Co}, \mathrm{Ni}$ and $\mathrm{Pb}$ were moderately enriched (1 $<\mathrm{EF}<3.5)$ above baseline concentrations during both seasons. These metals may have been elevated above background values due to both natural and anthropogenic inputs.

Significant spatial variations existed for all metals in the sediment during the dry and wet periods, with the highest levels of enrichment occurring at the mouth and in the lower reaches of the estuary (Fig. 7). When the mouth was closed, enrichment factors for all metals decreased significantly in a landward direction ( $\mathrm{p}<0.05)$, with $\mathrm{Cd}$, $\mathrm{Co}$ and $\mathrm{Pb}$ maintaining this gradient during the wet season. This spatial distribution of metals thus appeared to reflect the land-use gradient along the East Kleinemonde Estuary during both seasons, since the majority of developments are situated along the beach-front and the banks of the lower reaches.

Total organic content did not have a significant effect on controlling the concentrations of most metals (with the exception of Fe and Zn) within the East Kleinemonde Estuary sedi-

ments (Table 5). Iron was positively correlated to the fine grained sands and mud during both seasons $(\mathrm{R}>0.75 ; \mathrm{p}<0.01)$ indicating that Fe was a good normalising element for grain size. Fairly high negative correlations were observed between TOC and $\mathrm{Cd}, \mathrm{Cu}, \mathrm{Co}$ and $\mathrm{Pb}$ when the mouth was open $(\mathrm{R} \geq-0.50$; $\mathrm{p}<0.05$ ). Strong positive correlations existed between the concentrations of $\mathrm{Pb}$ and $\mathrm{Cd}(\mathrm{R}>0.80, \mathrm{p}<0.01)$ during both closed and open mouth phases, indicating that these metals were either from the same source or that their distribution was controlled by similar physico-chemical parameters. Both $\mathrm{Cd}$ and $\mathrm{Pb}$ were also strongly correlated to the 'medium sand' fraction (250 to $500 \mu \mathrm{m}$ ), which dominated the mouth and lower reaches, during the wet season. Most of the residential development is restricted to the lower reaches of the estuary and thus $\mathrm{Pb}$ may have been entering the system from non-point sources such as runoff from the motorway and parking lots.

It is unusual that there was little correlation between most metals and grain size, TOC and Fe content of the sediments. Such a lack of correlation usually indicates anthropogenic input of the metals (Acevedo-Figueroa et al., 2006). Understanding the geochemistry of East Kleinemonde Estuary sediments is how- 
ever beyond the scope of this project and it is not possible to decipher the exact physico-chemical interactions taking place in the sediments given the current data set. The variability in metal-sediment interactions may be due to variations in the underlying bedrock, as well as variations in anthropogenic and oceanic inputs of the metals.

The mean $( \pm \mathrm{SD})$ concentration of $\mathrm{Pb}$ in the water of the East Kleinemonde Estuary during the closed and open mouth phases were $2.46 \pm$ $1.407 \mu \mathrm{g} \cdot \ell^{-1}$ and $3.71 \pm 2.41 \mu \mathrm{g} \cdot \ell^{-}$ ${ }^{1}$ respectively. The mean $( \pm \mathrm{SD})$ concentration of $\mathrm{Cd}$ in the water of the East Kleinemonde Estuary during the closed and open mouth phases were $0.110 \pm 0.207 \mu \mathrm{g} \cdot \ell^{-1}$ and $0.386 \pm 0.616 \mu \mathrm{g} \cdot \ell^{-1}$, respectively. When there was increased freshwater inflow the concentrations of $\mathrm{Pb}$ and $\mathrm{Cd}$ in the water increased in a landward direction, suggesting fluvial or terrestrial input (Figs. 8A and 8B). The concentrations of $\mathrm{Pb}$ and Cd both fell well below the South African recommended water quality guidelines for coastal marine waters (DWAF, 1995), and thus the East Kleinemonde Estuary was uncontaminated with these metals at the time of sampling.

\section{Riet Estuary}

The mean concentrations of metals in the sediment of the Riet Estuary during both the dry season and wet seasons are presented in Table 2. Temporal variations in sediment metal concentrations were observed, but the variations were not significant $(p>0.05)$ for all metals except $\mathrm{Ni}$, which increased significantly during the wet season $(\mathrm{p}<0.05)$.

Evidence for enrichment of metals was obtained by superimposing metal concentrations for the Riet Estuary on baseline metal vs. Fe linear regression models (Fig. 9). Cobalt, $\mathrm{Ni}$ and $\mathrm{Pb}$ were enriched in several samples during both the dry and wet seasons (Figs. 9A, 9C and 9D), while sediments were only enriched with $\mathrm{Cu}$ during the dry season. Sediments were evidently more enriched with Ni during the wet season, with the majority of samples falling above the upper 95\% prediction limit (Fig. 9C). Zinc concentrations fell within the predicted baseline concentration range during both seasons.

There were no significant temporal changes in the average enrichment factors for all metals except Ni within the Riet Estuary sediment (Table 3), and this may be due to the small size of the catchment and the limited development around the estuary. Calculation of enrichment factors revealed that, on average, sediments were not enriched with $\mathrm{Cu}$ and $\mathrm{Zn}$ during both seasons $(\mathrm{EF}<1)$. The Riet sediments were not enriched with $\mathrm{Ni}$

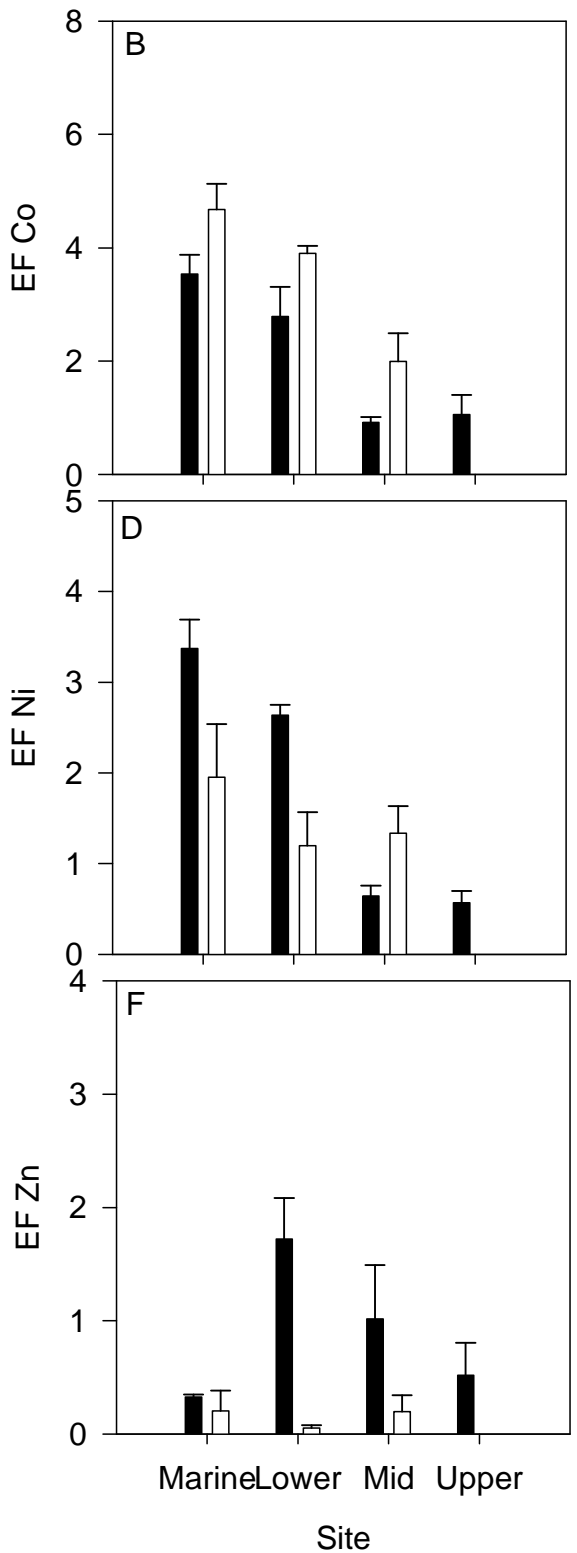

Figure 7

Site

East Kleinemonde Estuary during open and closed mouth phases. No data were obtained for the upper reaches during the open mo - Mouth closed (dry season), $\square$ Mouth open (wet season).

during the dry season but were enriched during the wet season $(1<\mathrm{EF}<2)$. Cadmium, Co and $\mathrm{Pb}$ exhibited moderate enrichment during both seasons $(1<\mathrm{EF}<4)$, with Cd having the highest enrichment factors.

The Riet Estuary displayed similar spatial variations in metals as the East Kleinemonde Estuary, with the highest levels of enrichment occurring in the marine environment and lower reaches (Figs. 10A to 10F). During the dry season, all metals except $\mathrm{Zn}$ were significantly more enriched $(\mathrm{p}<0.05)$ in the marine environment and lower reaches as compared to the middle and upper reaches. During the wet season, the only metals that showed significant spatial variation $(\mathrm{p}<0.05)$ were $\mathrm{Co}, \mathrm{Ni}$ and $\mathrm{Pb}$, which decreased significantly in a landward direction. There was thus less spatial variation in metal enrichment during the wet season, and this is probably due to the mixing and scouring of sediments caused by the increased freshwater inflow. 


\begin{tabular}{|c|c|c|c|c|c|c|c|c|c|c|c|c|c|}
\hline \multicolumn{14}{|c|}{$\begin{array}{l}\text { TABLE } 6 \\
\text { A) Spearman rank order correlations (R) for metals concentrations and sediment properties for the Riet sediments (dry season) }\end{array}$} \\
\hline & $\mathrm{Cd}$ & Co & $\mathrm{Cu}$ & $\mathrm{Fe}$ & $\mathrm{Ni}$ & $\mathrm{Pb}$ & Zn & TOC & $\begin{array}{c}\text { Coarse } \\
\text { sand }\end{array}$ & \begin{tabular}{c|c|c|c|} 
Medium \\
sand
\end{tabular} & $\begin{array}{l}\text { Fine } \\
\text { sand }\end{array}$ & $\begin{array}{l}\text { Very } \\
\text { fine } \\
\text { sand }\end{array}$ & mud \\
\hline Cd & 1.00 & & & & & & & & & & & & \\
\hline Co & $0.91 *$ & 1.00 & & & & & & & & & & & \\
\hline $\mathbf{C u}$ & $0.81^{*}$ & $0.85^{*}$ & 1.00 & & & & & & & & & & \\
\hline $\mathbf{F e}$ & -0.15 & 0.06 & 0.16 & 1.00 & & & & & & & & & \\
\hline $\mathrm{Ni}$ & 0.84* & $0.90^{*}$ & 0.97* & 0.15 & 1.00 & & & & & & & & \\
\hline $\mathbf{P b}$ & $0.87^{*}$ & 0.93* & 0.81* & -0.01 & $0.83^{*}$ & 1.00 & & & & & & & \\
\hline $\mathbf{Z n}$ & 0.47 & 0.34 & 0.46 & 0.55 & 0.48 & 0.17 & 1.00 & & & & & & \\
\hline TOC & -0.13 & 0.02 & 0.13 & $0.95 *$ & 0.13 & -0.06 & 0.63 & 1.00 & & & & & \\
\hline Coarse sand & -0.50 & -0.54 & -0.28 & -0.20 & -0.34 & -0.48 & -0.37 & -0.23 & 1.00 & & & & \\
\hline Medium sand & 0.58 & 0.61 & 0.64 & -0.37 & 0.65 & 0.70 & -0.22 & -0.43 & -0.07 & 1.00 & & & \\
\hline Fine sand & -0.52 & -0.59 & -0.59 & 0.37 & -0.59 & -0.64 & 0.27 & 0.43 & 0.06 & $-0.92 *$ & 1.00 & & \\
\hline Very fine sand & $-0.75 *$ & $-0.73 *$ & -0.68 & 0.36 & -0.69 & $-0.83^{*}$ & 0.09 & 0.42 & 0.24 & $-0.94 *$ & $0.80 *$ & 1.00 & \\
\hline Mud & $-0.76^{*}$ & $-0.74 *$ & -0.69 & 0.36 & -0.70 & $-0.84 *$ & 0.09 & 0.41 & 0.22 & $-0.94 *$ & $0.81^{*}$ & $0.99 *$ & 1.00 \\
\hline \multicolumn{14}{|c|}{ B) Spearman rank order correlations (R) for metals concentrations and sediment properties for the Riet sediments (wet season) } \\
\hline Cd & 1.00 & & & & & & & & & & & & \\
\hline Co & 0.38 & 1.00 & & & & & & & & & & & \\
\hline $\mathbf{C u}$ & 0.07 & -0.12 & 1.00 & & & & & & & & & & \\
\hline Fe & -0.33 & -0.43 & 0.74 & 1.00 & & & & & & & & & \\
\hline $\mathbf{N i}$ & 0.74 & 0.52 & 0.00 & -0.24 & 1.00 & & & & & & & & \\
\hline $\mathbf{P b}$ & 0.61 & 0.64 & -0.43 & -0.79 & 0.43 & 1.0 & & & & & & & \\
\hline Zn & -0.07 & -0.21 & 0.71 & 0.75 & -0.14 & -0.77 & 1.00 & & & & & & \\
\hline TOC & -0.32 & -0.47 & 0.75 & 0.99 & -0.29 & -0.81 & 0.79 & 1.00 & & & & & \\
\hline Coarse sand & -0.67 & -0.64 & 0.52 & 0.83 & -0.62 & -0.96 & 0.68 & 0.86 & 1.00 & & & & \\
\hline Medium sand & 0.62 & 0.71 & -0.60 & -0.81 & 0.55 & 0.96 & -0.57 & -0.83 & -0.93 & 1.00 & & & \\
\hline Fine sand & 0.00 & -0.31 & 0.12 & -0.02 & -0.24 & 0.43 & -0.54 & -0.01 & 0.00 & -0.07 & 1.00 & & \\
\hline Very fine sand & -0.67 & -0.74 & 0.50 & 0.79 & -0.52 & -1.00 & 0.50 & 0.80 & 0.95 & -0.98 & 0.05 & 1.0 & \\
\hline Mud & -0.69 & -0.67 & 0.48 & 0.81 & -0.43 & -0.96 & 0.43 & 0.80 & 0.90 & -0.95 & 0.02 & 1.0 & 1.00 \\
\hline
\end{tabular}

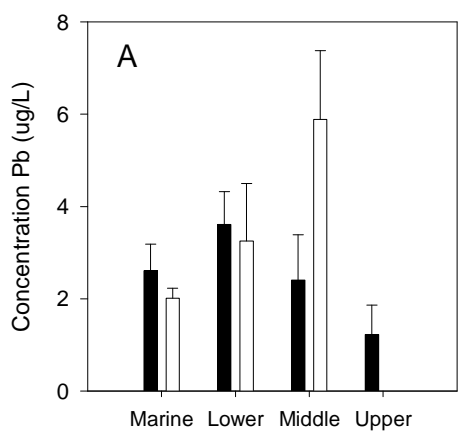

Site

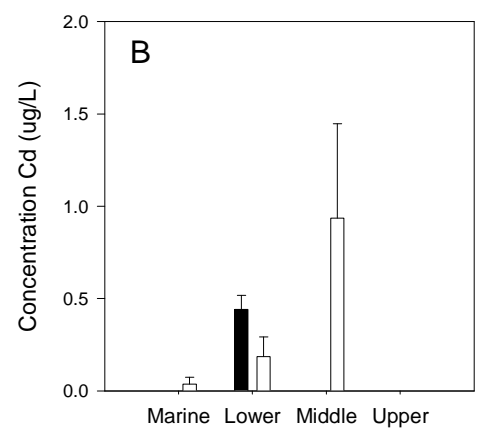

Site

Figure 8

Spatial and temporal variations in the mean $( \pm S D)$ concentrations of $P b$ and $\mathrm{Cd}$ in water collected from the East Kleinemonde Estuary when the mouth was closed and open. Note: No data were obtained for the upper reaches during the open mouth phase as this part of the estuary was inaccessible during this time.

- Mouth closed (dry season),

$\square$ Mouth open (wet season)

Positive correlations were observed between, $\mathrm{Pb}, \mathrm{Cd}, \mathrm{Ni}$, $\mathrm{Co}$ and $\mathrm{Cu}$ during the dry season (Table 6A). These metals were also associated with the medium sized sand fraction, which was predominantly found in the mouth and lower reaches of the estuary. Positive correlations still existed between $\mathrm{Pb}, \mathrm{Cd}, \mathrm{Ni}$, Co and

the medium sand fraction during the wet season (Table 6B). Cadmium Co, Ni and Pb were negatively correlated to the mud and TOC content of the sediments during both seasons. As with the East Kleinemonde Estuary this is 'atypical' of natural systems and usually suggests anthropogenic input of metals. However, given the small size of the estuary and the limited developments in its surroundings it is unlikely that the seaward increase in metal concentrations and lack of association betweens metals and TOC, Fe and mud is entirely due to anthropogenic activities. It is possible that the metals are from a natural marine source, and more extensive analysis of sediment composition (Al, $\mathrm{Mn}, \mathrm{CaCO}_{3}$ content) may have provided supplementary information on the source of the metals.

There was a slight reduction in the mean concentrations of $\mathrm{Pb}$ and $\mathrm{Cd}$ in the water collected from the Riet when the mouth of the estuary was open (Figs. 11A and 11B), but the difference was not significant. The mean $( \pm \mathrm{SD})$ concentrations of $\mathrm{Pb}$ and $\mathrm{Cd}$ in the water when the mouth was closed were $2.747 \pm$ $1.751 \mu \mathrm{g} \cdot \ell^{-1}$ and $0.475 \pm 0.191 \mu \mathrm{g} \cdot \ell^{-1}$, respectively, and the mean concentrations when the estuary breached were $1.107 \pm 2.480 \mu \mathrm{g} \cdot \ell^{-1}$ and $0.362 \pm 0.430 \mu \mathrm{g} \cdot \ell^{-1}$, respectively. The mean concentrations of $\mathrm{Cd}$ and $\mathrm{Pb}$ at all sites were well below the South African recom- 

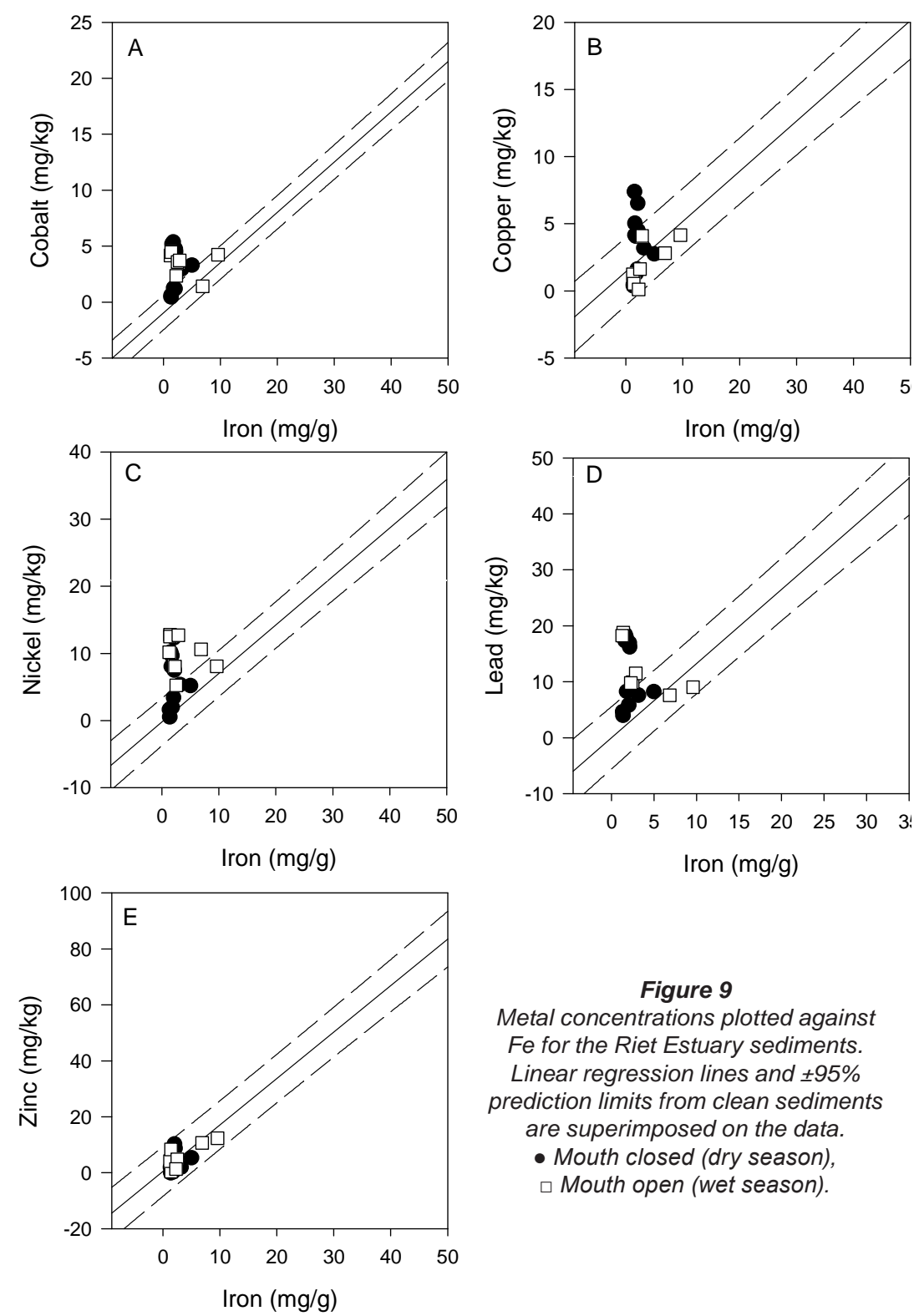

Figure 9

Metal concentrations plotted against

Fe for the Riet Estuary sediments. Linear regression lines and $\pm 95 \%$

prediction limits from clean sediments are superimposed on the data.

- Mouth closed (dry season),

$\square$ Mouth open (wet season). decreased in the East Kleinemonde Estuary. Cadmium is a common constituent of phosphate fertilisers, which are widely used in the Eastern Cape (Loewe, 2007), and it has been found that Cd may enter aquatic systems via the degradation these fertilisers (Bettet-Chambers, 1999). The elevated levels of $\mathrm{Cd}$ within these estuaries may thus be linked to the use of phosphate fertilisers within their catchments. It is possible that anthropogenic enrichment of Cd during the wet season is also coupled with geological enrichment, which would increase with higher levels of rainfall and runoff. The significant reduction in $\mathrm{Cd}$ concentrations in the water column of the Kariega Estuary during the wet season is likely to be as a result of the diluting effect of the increased flow of freshwater into the estuary. It may also be due to up-take of $\mathrm{Cd}$ from the water column by phytoplankton or suspended sediments.

The elevated enrichment of metals at the mouth and lower reaches of the estuaries studied is an interesting phenomenon, and at first sight appears to reflect the land-use gradient along the estuaries. It is however difficult to conclude that metals were elevated at these sites due to anthropogenic enrichment given the limitations of the current data set. It is possible that metal enrichment increased in a seaward direction as a result of natural processes that were not accounted for in data analysis. Phytoplankton blooms and upwelling events have been found to play an important role in the bio-geochemical cycling of metals, especially Cd, in the world's oceans and estuaries (Bruland et al., 1978; Takesue and Geen 2002). Biological uptake of metals from surface waters by phytoplankton and microplankton would lower concentrations of metals in the surface waters, and the

mended guidelines for those metals (DWAF, 1995).

The temporal variations differed for each estuary and each metal, possibly due to differences in the extent and type of development surrounding the estuaries, the magnitude and frequency of freshwater inflow, the biological uptake and cycling of metals within the estuary, the physico-chemical interactions between metals and sediment characteristics and differences in the underlying geology. Each estuary thus needs to be considered independently when trying to develop management strategies to prevent metal enrichment and contamination.

Cadmium and $\mathrm{Pb}$, elements of great environmental concern, displayed average enrichment factors of $0.75<\mathrm{EF}<4.07$ for $\mathrm{Cd}$ and $1.55<\mathrm{EF}<3.17$ for $\mathrm{Pb}$ within the three estuaries studied. These enrichment factors suggest minor to moderate enrichment of $\mathrm{Cd}$ and $\mathrm{Pb}$. Elevated rainfall resulted in an overall reduction in $\mathrm{Pb}$ concentrations and enrichment within the sediment and water of the Kariega and Riet Estuaries, whereas it resulted in an increase in $\mathrm{Pb}$ concentrations and enrichment within the water and sediment of the East Kleinemonde Estuary. Conversely, Cd enrichment increased in the sediments of the Kariega and Riet Estuaries during heavy rainfall, but organic detritus would return the $\mathrm{Cd}$ to the sediment. Cd is thus cycled in much the same way as $\mathrm{PO}_{4}$ and $\mathrm{NO}_{3}$, and in coastal waters where upwelling occurs, $\mathrm{Cd}$ will be carried to surface waters together with plant nutrients that stimulate plant growth (Bruland et al., 1978). Seasonal changes in phytoplankton density may thus be responsible for some of the variation seen in metal concentrations in the water column and sediment. Upwelling events are known to occur on the landward side of the Agulhas Current between East London and Port Elizabeth. The centre of this upwelling cell is adjacent to Port Alfred (a coastal town $\sim 40 \mathrm{~km}$ south west of the Kariega Estuary), and has a lateral range along the Agulhas Current of 85 to $300 \mathrm{~km}$ (Lutjeharms et al., 2000). This upwelling event, which occurs $40 \%$ of the time, contributes substantially to the high nutrient loads observed for this section of the coast (Lutjeharms et al., 2000). These continual upwelling events may have contributed to the enrichment of metals in the marine and estuarine sediments of the Kariega, East Kleinemonde and Riet Estuaries, although further research needs to be conducted to substantiate this hypothesis.

Cobalt enrichment was evident in the sediments of all three estuaries studied $(1.9<\mathrm{EF}<3.4)$, with the majority of samples 


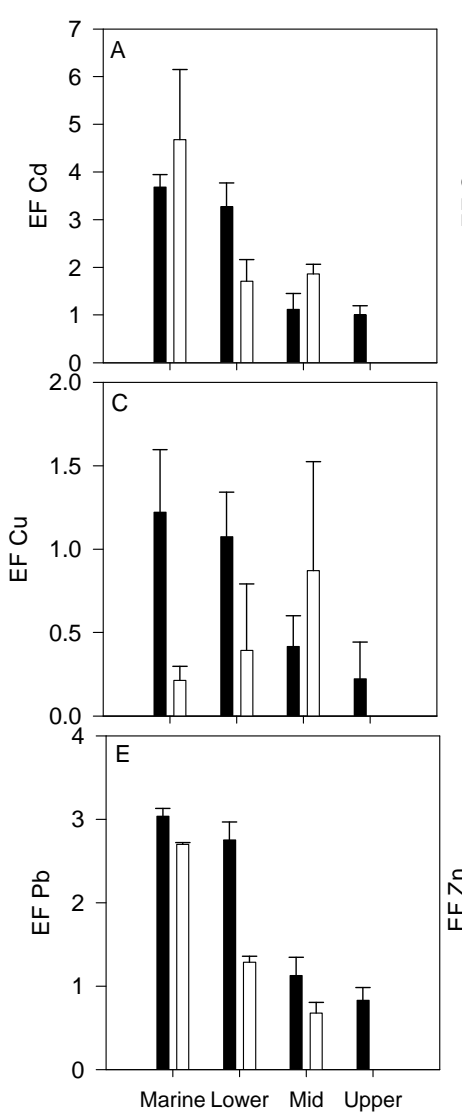

Site

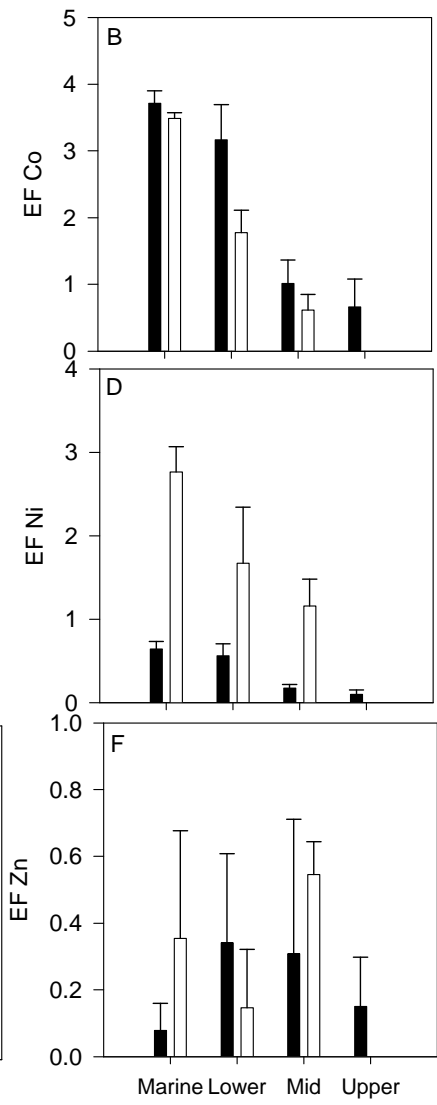

Site
Figure 10

Spatial variation in mean $( \pm S D$ ) enrichment factors (EF) for sediments taken from the Riet Estuary during open and closed mouth phases Note: No data were obtained for the upper reaches during the open mouth phase as this part of the estuary was inaccessible during this time.

- Mouth closed (dry season),

$\square$ Mouth open (wet season).

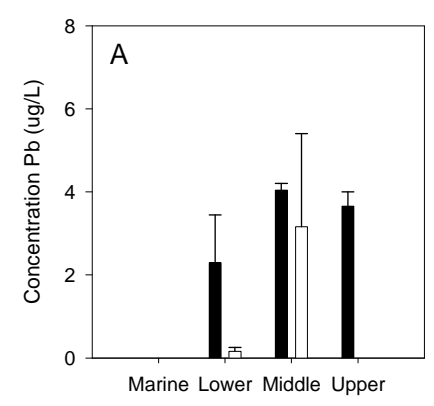

Site

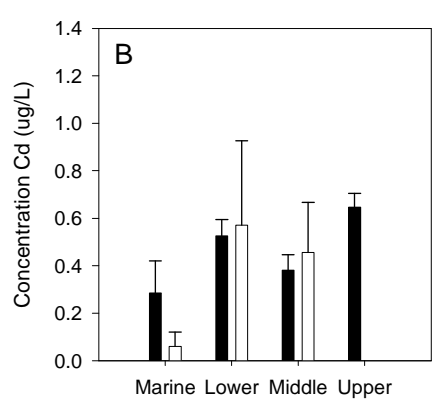

Site
Figure 11

Spatial and temporal variations in the mean $( \pm S D)$ concentrations of $\mathrm{Pb}$ and $\mathrm{Cd}$ in water collected from the Riet Estuary when the mouth was closed and open. Note: No data were obtained for the upper reaches during the open mouth phase as this part of the estuary was inaccessible during this time.

- Mouth closed (dry season)

$\square$ Mouth open (wet season) falling above the $95 \%$ prediction limit for the Co vs. Fe baseline regression model. Cobalt enrichment also consistently increased in a seaward direction for all the three estuaries during both seasons. This may suggest that Co is entering the estuaries from a marine source. Cobalt is an essential micronutrient for the growth of marine phytoplankton (TovarSanchez et al. 2004), and thus, like Cd, it may be enriched in the marine sediments due to biological cycling.

\section{Conclusions}

The effects of rainfall on metal concentrations and enrichment within estuarine sediment and water in the Kariega, Riet and East Kleinemonde Estuaries during both dry and wet seasons was investigated. The increased freshwater inflow led to a reduction in $\mathrm{Co}, \mathrm{Ni}$ and $\mathrm{Pb}$ enrichment in the sediments of the Kariega Estuary. The average concentrations of $\mathrm{Cd}$ and $\mathrm{Pb}$ in the water of the Kariega Estuary were higher than the South African water quality guidelines for coastal marine waters during the dry season, and decreased significantly during the wet season. Increased freshwater inflow appears to have played an important role in flushing metals from the sediment and water column of the Kariega Estuary during the wet season, and should be considered as a management strategy for preventing excessive accumulation of metals in the estuary. Temporal variations existed in metal concentrations and enrichment within the Riet and East Kleinemonde Estuaries, but the variations were less pronounced than in the Kariega Estuary.

Despite the minor to moderate enrichment of metals in the sediments of these estuaries since the study by Watling and Watling (1983), the absolute concentrations of metals are still relatively low. Metal contamination may not yet pose a threat to these estuarine environments. However, Eastern Cape rainfall is limited and impoundments together with poor catchment management may lead to the accumulation of metals in estuaries, particularly those in which coastal development occurs. It is thus important to consider the natural flow of an estuary when trying to limit contamination.

\section{Acknowledgements}

Thanks go to the National Research Foundation (NRF), Deutscher Akademischer Austausch Dienst (DAAD), Rhodes University and the Ernst and Ethel Eriksen Trust for financial support. We also thank Rhodes University Department of Zoology and Entomology and the Department of Biotechnology for providing laboratory facilities.

\section{References}

ACEVEDO-FIGUEROA D, JIMENEZ BD and RODRIGUEZSIERRA CJ (2006) Trace metals in sediments of two estuarine lagoons from Puerto Rico. Environ. Pollut. 141 336-342.

BADENHORST P (1998) Report on the Dynamics of the Kleinemonde West and East Estuaries (CSE 13 \& 14). CSIR Report EMA/T 8805. 14 pp.

BATE GC, WHITFIELD AK, ADAMA JB, HUIZINGA P and WOOLDRIDGE TH (2002) The importance of the river-estuary interface (REI) zone in estuaries. Water SA 28 (3) 271-280.

BCLME (2006) The Development of a Common Set of Water and Sediment Quality Guidelines for the Coastal Zone of BCLME, South Africa, CSIR Report No: CSIR/NRE/ECO/2006/0011/C. BETTET-CHAMBERS M, DAVIES P and KNOTT B (1999) Cadmium in aquatic ecosystems in Western Australia: A legacy of 
nutrient-deficient soils. J. Environ. Manage. 57 283-295.

BINEY CH, AMUZU AT, CALAMARI D, KABA N, MBOME IL, NAEVE H, OCHUMBE PB, OSIBANJO O, RADEGONDE V and SAAD MAH (1994) Review of heavy metals in the African aquatic environment. Ecotoxicol. Environ. Saf. 28 134-159.

BINNING K and BAIRD D (2001) Survey of heavy metals in the sediments of the Swartkops River Estuary, Port Elizabeth, South Africa. Water SA 27 (4) 461-466.

BROOKS RR, PRESLEY BJ and KAPLAN IR (1967) APDC-MIBK extraction system for the determination of trace elements in saline waters by atomic-absorption spectrophotometry. Talanta 14 809-816.

BRULAND KW, KNAUER GA and MARTIN JH (1978) Cadmium in northeast Pacific waters. Limnol. Oceanogr. 23 ( 4) 618-625.

BRYAN GW and LANGSTON WJ (1992) Bioavailability, accumulation and effects of heavy metals in sediments with special reference to United Kingdom estuaries: a review. Environ. Pollut. 76 89-131.

BUCHMAN MF (1999) NOAA Screening Quick Reference Tables, NOAA HAZMAT Report 99-1, Seattle WA, Coastal Protection and Restoration Division. National Oceanic and Atmospheric Administration. $12 \mathrm{pp}$.

BUNTSAMA J and CASEY-LEFKOWITZ S (1999) Summary Workshop: Nonpoint Source Water Pollution Compliance, Workshop Summary: 41 - Nonpoint Source Compliance. Proc. $5^{\text {th }}$ Int. Conf. on Environmental Compliance and Enforcement, 16-20 Nov 1998, Monterey, California, USA. International Network for Environmental Compliance and Enforcement 383-386.

CHEN CW, KAO CM, CHEN CH and DONG CD (2007) Distribution and accumulation of heavy metals in the sediments of Kaohsiung Harbour, Taiwan. Chemosphere 66 (8) 1431-1440.

DASKALAKIS KD and O'CONNOR TP (1995) Normalization and elemental sediment contamination in the coastal United States. Environ. Sci. Technol. 29 470-477.

DE GROOT AJ, SALOMONS WA and ALLERSMA E (1976) Processes affecting heavy metals in estuarine sediments. In: Burton LJW and Liss PS (eds.) Estuarine Chemistry. Academic Press, London. 131-157.

EURACHEM (1998) The Fitness for Purpose of Analytical Methods: A Laboratory Guide to Method Validation and Related Topics (Edn. 1). LGC Ltd. Teddington. United Kingdom.

FATOKI OS and MATHABATHA S (2001) An assessment of heavy metal pollution in the East London and Port Elizabeth harbours. Water SA 27 (2) 233-240.

GIBBS RJ (1994) Metals in sediments along the Hudson River Estuary. Environ. Int. 20 (4) 507-516.

GOBEL P, DIERKES C and COLDEWEY WG (2007) Storm water runoff concentration matrix for urban areas. J. Contam. Hydrol. 91 26-42.

GRANGE N and ALLANSON BR (1995) Influence of freshwater inflow on the nature, amount and distribution of seston in estuaries of the Eastern Cape, South Africa. Est. Coast. Shelf Sci. 40 403-420.

HARRISON TD, COOPER JAG and RAMM AEL (2000) State of South African Estuaries; Geomorphology, Ichthyofauna, Water Quality and Aesthetics. State of the Environment Series, Report No. 2. Department of Environmental Affairs and Tourism, Pretoria, South Africa.

HENNIG HF-KO (1985) Review of metal concentrations in Southern African coastal waters, sediments and organisms. S. Afr. Natl. Sci. Programmes Rep. No 108, CSIR, Pretoria. South Africa.

JENNINGS ME (2005) Nutrient dynamics in and offshore of two permanently open South African estuaries with contrasting freshwater inflow. M.Sc. Thesis, Rhodes University, Grahamstown, South Africa.

KANAI H, INOUYE V, GOO R and WAKATSUKI H (1979) Solubility of 4-methyl-2-pentanone in aqueous phase of various salt concentrations. Anal. Chem. 51 1019-1021.

KENNISH MJ (1997) Practical Handbook of Estuarine and Marine Pollution. CRC Press Inc., New York, USA. 253-298.
LI X, SHEN Z, WAI OWH and LI YS (2001) Chemical forms of Pb, $\mathrm{Zn}$ and $\mathrm{Cu}$ in the sediment profiles of the Pearl River Estuary. Mar. Pollut. Bull. 42 (3) 215-223.

LIU WX, LI XD, SHEN ZG, WANG DC, WAI OWH and LI YS (2003) Multivariate statistical study of heavy metal enrichment in sediments of the Pearl River Estuary. Environ. Pollut. 121 377-388.

LOEWE M (2007) Fertilizer saga: supplier to face R70m lawsuit. The Herald, Saturday 13 July. Port Elizabeth, South Africa.

LUTJEHARMS JRE, COOPER J and ROBERTS M (2000) Upwelling at the inshore edge of the Agulhas Current. Cont. Shelf Res. 20 737-761.

NEWMAN BK and WATLING RJ (2007) Definition of baseline metal concentrations for assessing metal enrichment of sediment from the south-eastern Cape coastline of South Africa. Water SA 33 (5) 675-681.

PERRET D, GAILLARD JF, DOMINIK J and ATTEIA (2000) The diversity of natural hydrous iron oxides. Environ. Sci. Technol. 34 3540-3546.

ROACH AC (2005) Assessment of metals in sediments from Lake Macquarie, New South Wales, Australia, using normalisation models and sediment quality guidelines. Mar. Environ. Res. 59 453-472.

RSA DWAF (1995) Republic of South Africa Department of Water Affairs and Forestry, South African Water Quality Guidelines for Coastal Marine Waters 1. Natural Environment. Pretoria, South Africa.

RUIZ JM and SAIZ-SALINAS JI (2000) Extreme variation in the concentration of trace metals in sediments and bivalves from the Bilbao estuary (Spain) caused by the 1989-1990 drought. Mar. Environ. Res. 49 307-317.

SCHARLER UM and BAIRD D (2003) The influence of catchmen management and phytoplankton biomass of Eastern Cape estuaries, South Africa. Est. Coast. Shelf Sci. 56 753-748.

SCHROPP SJ, LEWIS G, WINDOM HL, RYAN JD, CALDER FD and BURNEY LC (1990) Interpretation of metal concentrations in estuarine sediments of Florida using aluminum as a reference element. Estuaries 13 (3) 227-235.

SCHUMACHER BA (2002) Methods for the Determination of Total Organic Carbon (TOC) in Soils and Sediments. United States Environmental Protection Agency, Las Vegas, United States.

STANDARD METHODS (1998) Standard Methods for the Examination of Water and Wastewater (20 ${ }^{\text {th }}$ edn.) Chapter 3. APHA, AWWA and WEF, Washington, USA.

SUMMERS JK, WADE TL, ENGLE VD and MALAEB ZA (1996) Normalization of metal concentrations in estuarine sediments from the Gulf of Mexico. Estuaries 19 (3) 581-594.

TAKESUE RK and GEEN (2002) Nearshore circulation during upwelling inferred from the distribution of dissolved cadmium off the Oregon coast. Limnol. Oceanogr. 47 (1) 176-185.

TAM NFY and YAO MWY (1998) Normalization of heavy metal contamination in mangrove sediments. Sci. Tot. Environ. 216 33-39.

TOVAR-SANCHEZ A, SANUDO-WILHELMY SA and FLEGAL AR (2004) Temporal and spatial variations in the biogeochemical cycling of cobalt in two urban estuaries: Hudson River Estuary and San Francisco Bay. Est. Coast. Shelf Sci. 60 (4) 717-728.

US-EPA (United States Environmental Protection Agency) (1996) Method 3050B, Acid Digestion of Sediment Sludges and Soils (2 ${ }^{\text {nd }}$ revision). December. 1-12.

US-EPA (United States Environmental Protection Agency) (1993) EPA 840-B-92-002 Guidance Specifying Management Measures for Sources of Nonpoint Pollution in Coastal Waters. Chapter 1: Polluted Runoff (January) (Nonpoint Source Pollution).

WATLING RJ (1988) Metal studies in the coastal environment of the Eastern Cape: A review. In: Bruton MN and Guess FW (eds.) Towards an Environmental Plan for the Eastern Cape. Grocott and Sherry. Grahamstown. South Africa.

WATLING RJ and WATLING HR (1983) Metal surveys in South African estuaries VII: Bushmans, Kariega, Kowie and Great Fish Rivers. Water SA 8 (2) 115-119. 